$7^{\text {th }}$ International Conference

«SCIENCE AND PRACTICE: A NEW LEVEL OF INTEGRATION

IN THE MODERN WORLD»

October 28, 2018, Sheffield, UK

Conference Proceedings

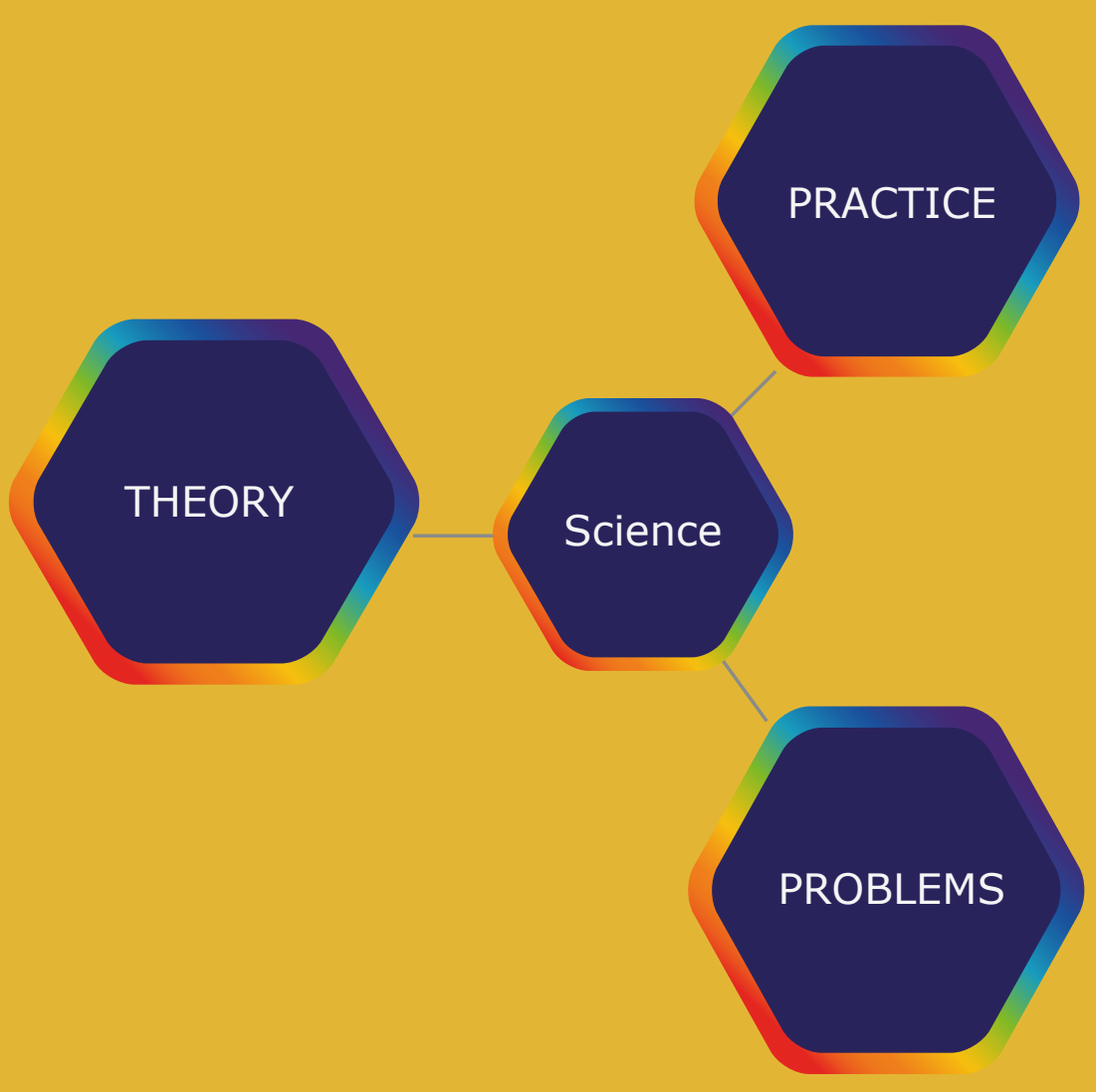


SCOPE ACADEMIC HOUSE 
SCOPE ACADEMIC HOUSE

B\&M PUBLISHING

$7^{\text {th }}$ International Conference

«SCIENCE AND PRACTICE: A NEW LEVEL OF INTEGRATION

IN THE MODERN WORLD»

October 28, 2018, Sheffield, UK

Conference Proceedings

Part 1

Scope Academic House

UK, S Yorkshire, Sheffield

B\&M Publishing

USA, San Francisco, California 
SCOPE ACADEMIC HOUSE

B\&M PUBLISHING

$7^{\text {th }}$ International Conference

«SCIENCE AND PRACTICE: A NEW LEVEL OF INTEGRATION

IN THE MODERN WORLD»

Science editor: Prof. R. Berton

Copyright (C) 2018

ISBN 978-1-941655-79-5

by Scope Academic House LTD

Office 1 Velocity tower

DOI: http://doi.org/10.15350/UK_6/7/1

10 st. Mary's gate

Sheffield

S Yorkshire

United Kingdom

S1 4LR

All rights reserved.

Published by B\&M Publishing.

For permission to use material from this text, please contact the publisher at

2076 - 16th Ave., Suite A,

San Francisco, California, USA 94116, 


\section{CONTENTS}

\section{ARCHITECTURE AND ART CRITICISM}

Conceptual architectural project - museum under open sky

(on the example of the medieval settlement of akhsikent of the Republic of Uz-

bekistan)

S. Valiev, K. Rakhimov

Influence of sufism on architecture and art

E. Barsukova

TECHNICAL SCIENCE

Aggregation of cultivator-plant feeder KHU-4T with tractor with adjustable

clearance

A. Akhmedov, Sh. Ahmedov

Substantiation of reliability of the fiber reinforced concrete superstructure de- 20 sign

for high-speed rail lines in the conditions of the Republic of Uzbekistan

E. Yakhshiev Z. Mirzaeva

\section{LAW}

The peculiarities of individuals who commit violent offenses in the family

A. Murodov

Registration of some non-traditional marks in some foreign countries

(legislation and practice revision)

Z. Babakulov

\begin{tabular}{ll}
\hline Stabilization clause in Uzbekistan legislation & 35
\end{tabular}

M. Yakubova

The system of advocateship and management of corporation: foreign experience 39

V. Davlyatov

The right to appeal: the experience of the states of the CIS and Asia 40

S. Yusupov

ECONOMICS

Actual factors of developing public finance system

M. Mansurov

$\begin{array}{ll}\text { Innovative development cotton processes in two products } & 48\end{array}$

A. Khasanov

PHILOLOGY

The instrumental syntaxeme in the structure of the english sentence

R. Khabipova

Conditional and unconditional sign

M. Rakhimova

Biographic method in "Ruzi choriyev's last will” $\quad 55$

Kh. Khudaymurodova

Adverb of time in English and Russian languages $\quad 57$

M. Abduvohidova

\begin{tabular}{ll}
\hline The importance of sociolinguistics as a linguistic discipline & 60
\end{tabular}

B. Kushakova

\begin{tabular}{ll}
\hline Morphological features of the verbal phraseological units & 62
\end{tabular}

D. Majidova

The value of matching prepositions in English and Tajik languages $\quad 64$

M. Mirzojonava

Proverbs and sayings in tajik and English languages

Z. Pulatova

MEDICAL SCIENCES

Analysis of concomitant changes in visual organs and organism

in cataract with anterior microphthalmos

D. Karimova, L. Babadzhanova, N. Umarova, A. Berdaliev 
Spread of HCV infection at different group of children and adults

M. Boboyev M. Madumarova

The estimation of hepatic encephalopathy in the patients with hepatocirrhosis 73 after portosystemic shunting

A. Devyatov A. Babadjanov S. Ruzibaev R. Baybekov

Types of anterior capsulorhexis using trepan blue dye in cataract extraction in $\quad 75$ children

L. Babadzhanova, D. Karimova, M. Mavlanov

Organization of medico-social researches and methods of the statistical analysis

M. Muyassarova, Sh. Abdurashitova, F. Yuldasheva, T. Rakhmonov, M. Makhsumov,

U. Tuymachev

PHILOSOPHY

Axiological aspects of middle eastern oriental philosophy

Z. Odinaeva 


\title{
ARCHITECTURE AND ART CRITICISM
}

\author{
CONCEPTUAL ARCHITECTURAL PROJECT - MUSEUM UNDER OPEN SKY \\ (ON THE EXAMPLE OF THE MEDIEVAL SETTLEMENT OF AKHSIKENT \\ OF THE REPUBLIC OF UZBEKISTAN)
}

\section{${ }^{1} S$. Valiev, ${ }^{2}$ K. Rakhimov}

\section{Abstract}

For the first time in Uzbekistan, the Architectural Project of the open-air museum in the ancient settlement of Ahsikent in the Namangan region was developed. The project provides for the creation of an indoor museum-reserve with the deployment of the appropriate infrastructure: a car park, a wind power plant for autonomous feeding and creating a microclimate at different times of the year, an electronic library, a visitor center serving visitors, a hotel, a cable car, and lecture rooms and classrooms In the classrooms, visitors will be able to try traditional crafts of residents who inhabited Akhsikent (making pottery, making bullet swords, etc.). Visitors will also have the opportunity to take part in archaeological excavations conducted on the territory of the reserve museum.

Keywords: architecture, ancient settlement of Akhsikent, open-air museum-reserve, architectural project, futurist museum.

Древние памятники Узбекистана имеют мировое значение, находятся под охраной ЮНЕСКО и являются, предметом пристального внимания как отечественных, так и зарубежных ученых, которые изучают историческую ценность данных памятников древности $[9,10]$. Из глубин веков до нас дошли останки древних городищ таких как Актепа Юнус-Абад, МингУрик, Шаштепа, Канка - в городе Ташкенте, Афросиаб - в Самаркандской области, Ахсикент - в Наманганской, Еркурган - в Кашкадарьинской, Дальверзинтепе - в Сурхандарьинской, Варданзи - в Бухарской, ТопракКала памятник зодчества Хорезма в Каракалпакистане и многие другие.

Поэтому большой интерес к древним городищам проявляют ученые архитекторы страны. Они изучают, как производилось строительство данного города в древности, какими жизнеобеспечивающими принципами руководствовались наши предки, как обустраивались жилища и коммуникационные системы древних городов $[1,2]$.

В связи с этим ученые архитекторы Самаркандского Государственного Архитектурно-строительного института им. М. Улугбека (Сам ГАСИ) впервые в Узбекистане пришли к идее создания музея под открытым небом на примере древнего городища Ахсикен и соответствующей урбанистической концепции, которую можно будет внедрить на других древних городищах не только Узбекистана, но и в странах Центральной Азии $[3,4,5,6,7,8]$.

Судя по археологическим данным, город возник в III веке до н.э. и являлся одним из крупнейших городов древнеферганского государства Давань. Так, по данным письменных источников, Ахси (Ахсикент, Ахсикет) - древний город Ферганы и удельная столица Саманидов. Расположен был на правом берегу реки Сыр-Дарьи у впадения в нее

1Sanzhar VALIEV, master student, (SamGASI), Uzbekistan.

${ }^{2}$ Kamol RAKHIMOV, Prof., Project Manager (SamGASI), Uzbekistan. 
Касансая. Согласно данным Ибн Хурдодбеха, Фергана - название области, просторной и богатой, с многочисленным населением. Столицу ее называют Ахсикет.

Раскопки жилых кварталов свидетельствуют о высоком уровне средневекового градостроительства и о благоустройстве жилищ Ахсикента, который в этом плане не уступал центральным городам Мавераннахра - Бухаре и Самарканду.

В настоящее время, с целью сохранить данное народное наследие и одновременно привлечь внимание к этому историческому памятнику, как местных, так и зарубежных туристов, нами разработан Архитектурный проект благоустройства «Музея заповедника под открытым небом Ахсикент» (Рис 1).

Весь исторический памятник укрывается оригинальным по архитектуре полусферическим куполом с отходящими лучами - коридорами, украшенными национальным восточным орнаментом. Рядом расположены три здания также с полусферическим куполом, где находятся вспомогательные историческому объекту элементы. Открывающийся вид сверху придает архитектурному комплексу, футуристический образ с элементами космического происхождения, имея в виду круги на полях оставляемые нашими инопланетными собратьями.

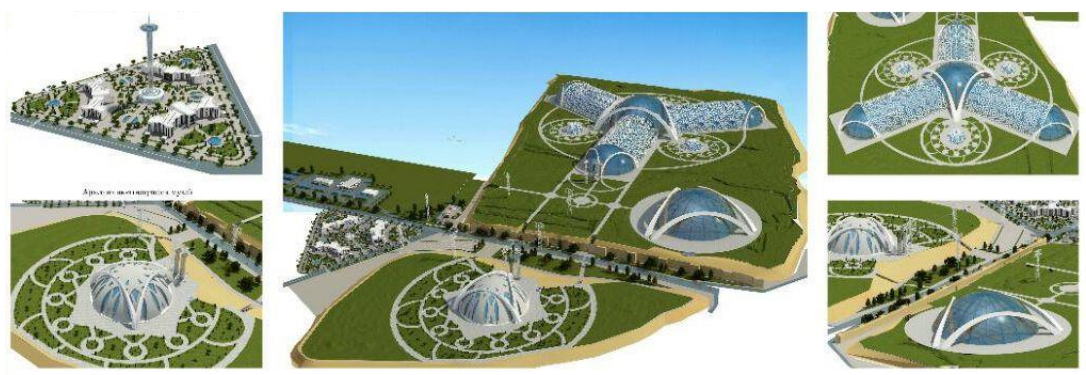

Рис. 1. Архитектурный проект музея Ахсикент

Данный проект, на наш взгляд, вызовет интерес мировой общественности в сфере истории, культуры, искусства, образования, археологии и обеспечит поток туристов и активное развитие туризма в этой области. Он явится своего рода маяком ориентации как способа современной реконструкции десятка других подобных городищ, распложённых как на территории Узбекистана, так и в Центральной Азии.

Проектом предусмотрены автомобильная стоянка, ветряная электростанция для автономного питания и создания микроклимата в различные времена года, электронная библиотека, визит-центр, обслуживающий посетителей, гостиница, канатная дорога, а также лекционные залы и учебные классы. В учебных классах посетители смогут попробовать заняться традиционными ремеслами жителей, населявших Ахсикент (изготовление глиняной посуды, изготовление «дамасских» мечей и др.). Посетители также будут иметь возможность принять участие в археологических раскопках, проводимых на территории музея заповедника. В настоящее время использование новых технологий и их внедрение становятся необходимыми условиями развития Узбекистана. 


\section{References}

[1] Азимджанова С.А. К истории Ферганы второй половины ХУ в. - Ташкент, 1957

[2] Анарбаев А.А. Благоустройство средневекового города Средней Азии. - Ташкент, 1981

[3] Валиев С.Р., Рахимов К.Д. Ахсикент - музей под открытым небом. Международный педагогический журнал «Наука 21 века» // Сб. статей, часть 1, Красноярск, апрель, 2018г., с. 77-78.

[4] Валиев С.Р., Рахимов К.Д. Архитектурный проект музея-заповедника Ахсикент под открытым небом. // Международный научный журнал Инновационное развитие, г. Пермь, № 2 (19), 2018 г., с. 65 - 67

[5] Валиев С.Р., Рахимов К.Д. История формирования городища Ахсикент. Тарихий манбашунослик, тарихнавислик, тарих тадкикотлари методлари ва методологиясининг долзарб масалалари мавзудаги Республика X илмий-назарий конференциясининг материаллари. - Ташкент, 2018, с. 79 - 83

[6] Рахимов К.Д., Валиев С.Р. Архитектурный проект - Музейный комплекс под открытым небом (на примере древнего городища Ахсикент). Свидетельство о депонировании интеллектуальной собственности в государственной фундаментальной библиотеке Академии наук Р.Уз. (авторские права), Рег.№ 3236, дата депонирования 28.02.2018 - 4 с.

[7] Rakhimov K., Uralov A., Valiev S. Architectural and landscape typology of gardens and parks of Tamerlane the Great, of similarity and their continuity in the gardens and parks «The Epochs of the Italian Renaissance». - Sertificate of copyright № KC01-001595, European depository Germany, Berlin, 2018, - 46 c.

[8] Valiev S., Rakhimov K.Dj. Architectural project of the Akhsikent open-air museum reserve. // Student science research works. - Conference Proceedings, San Francisco, USA, Pert I, March 30, 2018, p. 113 - 117

[9] Operational Guidelines for the Implementation of the World Heritage Convention. Paris: UNESCO. 2005.

[10]Convention Concerning the Protection. 1972, www.unesco.org 


\section{INFLUENCE OF SUFISM ON ARCHITECTURE AND ART}

\section{E. Barsukova}

\section{Abstract}

This article is considered of the influence of Sufism on the architecture and the art of the Muslim's Orient. There are some texts are considered containing rules and requirements to any craft, which indicate the involvement of Sufis and their influence on this or other kind of art. These prescriptions indicate the main purpose of Sufism - the upbringing of the "perfect man (al-Insān al-Kāmil)".

Keywords: architecture, decoration, Islam, Sufism, craft, treatise, philosophy, mysticism.

В последнее время наблюдается особый интерес к суфизму со стороны исследователей, являющемуся одним из ярчайших примеров развитой философии, охватившей многие стороны человеческой жизни. В нашей республике суфизм официально объявлен историко-культурным наследием [1], и именно поэтому на территории Узбекистана восстанавливаются все мавзолеи, где захоронены суфийские лидеры и их последователи.

Нами была поставлена задача выявить влияние суфизма и его философскоэтических основ на архитектуру и искусство ислама. Для решения этой задачи нами были проанализированы некоторые тексты, содержащие правила и требования к какому-либо ремеслу. В них указывается так же на причастность суфиев и их влияние на то или иное искусство.

По этому вопросу существует ряд точек зрений. Подтверждение тому, что суфии были тесно связаны и оказали влияние на искусство и ремесла можно обнаружить в трактатах: «0 ремесле» [2], «0 каллиграфах и художниках» [3], «Устав цеха живописных дел мастеров» [4]. В уставах (рисаля) излагалась легендарная история ремесла, основоположником и покровителем которого объявлялся обычно один из наиболее почитаемых мусульманских святых. Устав также служил как своеобразный религиозно-этический кодекс, регламентирующий обязанности членов цеха.

В «Уставе цеха живописных дел мастеров» указываются 12 выдающихся мастеров живописи, которые достигли полноты совершенства. Здесь же приводятся предписания что должен делать мастер, входя в мастерскую, приготавливая кисти к работе и т.д. Устав содержит и обязанности (всего их семь), надлежащих к исполнению художником [5. с.151]. Также приводится список имён пиров шариата, тариката, хакиката и мазхаба. А как известно, почти на всем протяжении истории суфизма можно наблюдать деление пути мистического самоусовершенствования на три основных этапа: шариа, тарика и хакика. Устав пользовался популярностью в кругу средневековых мастеров кисти.

Первый этап - «шариат»», т.е. буквальное выполнение откровенному закону. Лишь тогда, когда человек созрел и усвоил основные догмы ислама, то перед ним может раскрыться второй этап «тарикат» - букв. «дорога, путь». Третий этап обозначает «реальное, подлинное бытие» - «хакикат». Достигнув хакикат, путник, конечно интуитивно, познает истинную природу Божества и свою сопричастность ей.

\footnotetext{
${ }^{1}$ Elena BARSUKOVA, senior teacher, doctoral student of Tashkent Institute of Architecture and civil engineering, Uzbekistan.
} 
Потому-то суфии часто называют себя ахл ал-хакика - «люди подлинного бытия» [6].

В суфийском учении символы подразделяются на 2 категории: универсальные (свастика и др.) и специфические символы (заметны и понятны только для «посвященных»). В материальном мире богатейший внутренний мир суфиев проявлялся не только через их специфическую практику, но и через архитектуру, которую они украшали каллиграфией, арабесками, геометрическими символами.

О причастности суфиев к искусству указывает исследователь Э. Гюль [7], ссылаясь на Ремпеля Л.И.[8]. Расцвету геометрического орнамента (IX - XII вв.) способствовали «успехи точных наук и строительного дела...» [8, с.144]. Этот вид архитектурного декора призван был передать идеал сверхчувственной красоты раннеисламской эпохи. С идеями суфизма связывают распространение растительного орнамента [7]. Эпиграфический декор возникает в период адаптации доисламских культов в суфийском течении ислама (X-XII вв.), а массовое его применение в архитектуре наблюдается в период правления Тимура и тимуридов, именно в тот период, когда суфийские общины достигают подавляющего влияния в духовной жизни народов Средней Азии.

Второй этап (тарикат) обучения на Пути, в частности, 7 ступеней («макамат») становления ученика ищущий визуализирует его посредством геометрических фигур, составляющие основу геометрического орнамента «гирих». На этом же этапе идёт очередной прогресс развития, очередная стабилизация на Пути - это так называемое состояние Божественной милости или магические дары («ахвал»). Этот отрезок мистического пути суфия в материальном мире проявляется в виде великолепнейшего орнамента «арабеска». Третий этап «хакикат» в материальном мире проявляется посредством каллиграфии. В суфизме каллиграфия обозначает Божественное Присутствие в суфии («Hadrat»). Каллиграфия суфия, самые священные из художественных форм, напоминает Слово, которым Бог называет Себя [9, с.103]. Каллиграфия является универсальным суфийским символом, обладающим выразительным диапазоном геометрической формы, который позволяет ему интегрироваться в любой вид поверхностного украшения.

Следующий документ, указывающий на связь суфизма с искусством - это трактат «0 ремесле» Мир Финдириски (даты жизни ок. 1572 - 1640), анализ которого провёл Шахрам Пазуки [10, с.199]. Он пишет, что понятие «ремесло» (сан'аm) для мусульманских философов и мистиков имело особый смысл, который не имеет принципиального отношения к технологии Нового времени. «Трактат о ремеслах» Мир Финдириски является одной из лучших работ на эту тему, вышедших из-под пера выдающегося мыслителя и мистика. В трактате «Рисала-йи сина'иййа» ремесло и искусство рассмотрены в том числе и в философском и мистическом аспектах. А как известно, суфизм и гнозис присутствовали в исламской мысли, философии, культуре и искусстве испокон веков.

Основная мысль трактата заключается в том, что ремесла и искусства, в том или ином аспекте, имеют основание в суфизме и философии либо связаны с ними. Это подтверждают следующие положения этой связи [10, с.201]. В самом общем смысле термин «ремесло» (сан'ат) указывает на всякое занятие. В глазах философов и мистиков ремесла являлись и занятиями, и одновременно путями духовного странствия. Поэтому одним из условий принятия в члены суфийского братства, как правило, являлось овладение неким ремеслом. Обучение же ремеслу начиналось с обучения правилам очищения души и самоконтроля. Считалось, что всякое ремесло имеет божественное происхождение, в начале цепочки стояло имя того 
или иного пророка либо святого. Но чаще всего в начале цепочки учителей стояло имя имама Али, считавшегося духовным наследником Пророка. Имя Али также стоит в начале цепочки большинства суфийских орденов. В своём трактате Мир Финдириски разделил ремёсла на двенадцать категорий. Это свидетельствует о том, что данное деление представляется для автора особенно важным [10, с.207]. Он утверждает, что внутри каждого ремесла сокрыта мудрость и философия.

О связи с искусством, в частности с архитектурой, пишет и Идрис Шах [12], считая, что строителями храма царя Соломона в Иерусалиме были суфийские архитекторы Абд аль-Малика, построившие Купол Скалы на развалинах храма Соломона, и их последователи. Их настоящими именами были бан Абд-аль-Файз (Изз) и его «великий внук» Ма'руф, сын (ученик) Давида Таи, суфийское имя которого было Соломон, так как он был «сын Давида». Далее он указывает на то, что архитектурные пропорции, избранные для храма, как для Каабы в Мекке, соответствовали цифровым эквивалентам определенных арабских корней, передающих священные послания; при этом каждая часть здания соотносилась с любой другой в строго определённой пропорции [11, с.220]. С развитием суфизма на раннем этапе появляются такие архитектурные сооружения как ханака обитель и ритуальный зал суфиев, а позднее мемориальные комплексы с захоронением почитаемого шейха (хонако Дехкан-бобо, Баха ад-Дина Накшбанда, Касим Шейха и др.). Беспрецедентное развитие в мусульманском искусстве получает архитектурный орнамент, ставший проводником на пути эзотерического постижения истины как выражение красоты божественного творения. Он был «не просто декорацией, не вольным украшением предметов быта, но необходимым и важнейшим смысловым конструктом бытия ислама» [7].

В качестве выводов отметим то, что бесценный вклад в сокровищницу мировой архитектуры внесли мусульманские зодчие, достигшие самых высоких вершин этого нелегкого мастерства и создавшие особый, неповторимый архитектурный стиль, то есть исторически сложившуюся совокупность художественных средств и приемов. Большое значение имеет тот факт, что самые выдающиеся произведения мусульманского искусства и архитектуры являются суфийскими $[11$, с.11] (ансамбль Тадж-Махал в Агре. Индия; ансамбль Регистан в Самарканде. Узбекистан). А также что для каждого региона Узбекистана соответствует свой неповторимый колорит в архитектурно-декоративной графике культовых сооружений. Такое различие обусловлено и тем, что в разных регионах существовали свои школы суфийского обучения, имевшие свои отличительные особенности, которые выражались посредством цветосветовой символики [12].

\section{References:}

[1] Б. Бабаджанов. Возрождение деятельности суфийских групп в Узбекистане. Сб. ст. памяти Фритца Майера (1912-1998) / Сост. и отв. редактор А. А. Хисматулин. - СПб.: Филологический факультет СПбГУ, 2001. - 332с.

[2] Пазуки Шахрам. Ма'на-йи сан'ат дар хикмат-и исламй: шарх ва тахлйл «Рисала-йи сина'иййа» Мир-и Финдириски // Хираднама-йи Садра, 48 (1386/2007), с. 95-106, с небольшими сокращениями (примеч. перев.); Впервые этот трактат был издан литографическим способом в 1267/1850 г. в Индии.

[3] Кази Ахмад б. Хусайн ал-Хусайни Куми. Трактат о каллиграфах и художниках (датирован 1596/1597г.). Перевод и предисловие Б.Заходера. 1947. //http://www.farhangalshia.narod.ru/karbin/kazi7.html

[4] Устав цеха живописных дел мастеров (конец 14 - начало 15 вв.). Семенов А. А. Описание персидских, арабских и турецких рукописей Фундаментальной Библиотеки Среднеазиатского Гос. университета. Ташкент, 1935, с.65, №115/2. Перевод был впервые опубликован в журнале «Проблемы востоковедения», 1950, №3, с. 106-109. 
[5] Устав цеха живописных дел мастеров (конец 14 - начало 15 вв.). Предисловие, перевод и примечания Э. Дарского // Мастера искусства об искусстве. Т. 1. Средние века. Под ред. А. А. Губера и В. В. Павлова. М.: «Искусство», 1966. С. 147 - 152.

[6] Хисматулин А.А. Суфизм. - СПб.: Изд. дом «Азбука - классика», 2008. -192 с.; Х. К. Йылмаз. Тасаввуф и тарикаты. Перевод с турецкого. М.: 000 «Издательская группа «САД», 2007. 300 с. 1-е издание.

[7] Гюль Э. Суфизм и искусство орнамента. //SANAT//. Вып. 3. Ташкент, 2000. http://sanat.orexca.com/2000-rus/2000-3-2/elmira_gul-5/ (дата обращ. 13.07.18).

[8] Ремпель Л.И. Искусство Среднего Востока. Избранные труды по истории и теории искусств. М., 1978. -281 с.

[9] Laleh Bakhtiar «SUFI». Thames \& Hudson; Reissue edition (May 2004). L., P.120.

[10] Шахрам Пазуки. Смысл понятия «Ремесло» в исламской философии: анализ трактата Мир Финдириски Рисала-йи сина'иййа. Ишрак: ежегодник исламской философии: 2014. № 5 / Ishraq: Islamic Philosophy Year book: 2014. No.5. - М.: Наука - Вост. лит., 2014, с.199.

[11] Шах И. Суфии. - М.: Из-во «Локид - Пресс», 2001. - 448 с.

[12] Барсукова Е.Г. Влияние света и цвета на исламскую архитектуру. //Архитектура и строительство Узбекистана// Ташкент, 2015, №3-4, с.30. 


\title{
TECHNICAL SCIENCE
}

\section{AGGREGATION OF CULTIVATOR-PLANT FEEDER KHU-4T WITH TRACTOR WITH ADJUSTABLE CLEARANCE}

\author{
${ }^{1} \mathrm{~A}$. Akhmedov, ${ }^{2} \mathrm{Sh}$. Ahmedov
}

\section{Abstract}

In the article some results of studies on testing the possibility of aggregation of the cultivator-plant feeder KHU-4T with a tractor with adjustable clearance TTZ-1033 for interrow cultivation of cotton crops are given. As a result of the works carried out, it is established that the cultivator-plant feeder KHU-4T is aggregated with the TTZ-1033 tractor without any notice and can be used for inter-row cultivation of cotton crops and accompanying crops.

Keywords: tractor, ground clearance, cultivator, working elements, aggregate, cotton, inter-row processing, loosening of soil, weed.

Введение. Из-за высокой агротехнической проходимости для междурядных обработок посевов хлопчатника используют трехколесные универсально-пропашные трактора. Однако они, как показали исследования [1], имеют следующие существенные специфические недостатки:

- отрицательное техногенное воздействие на почву за счёт увеличения общей площади покрытия следами колес;

- увеличения максимального давления на почву в зоне опорной площади ходового аппарата, особенно под передним колесом;

- не рациональное распределение массы машинотракторного агрегата (МТА) по осям;

- увеличения зоны воздействия ходового аппарата на стебли, цветочки и плодовые элементы хлопчатника;

- низкую поперечную устойчивость, исключающую применение их в составе транспортных агрегатов по условиям безопасной эксплуатации;

- ограниченные тягово-сцепные качества и малую суммарную грузоподъемность шин, исключающую агрегатирование их с широкозахватными орудиями;

- сложность создания достаточно эффективной полноприводной конструкции трактора;

- не востребованность в сельскохозяйственном производстве в течение почти 4-5 (с ноября по март) месяцев;

\footnotetext{
${ }^{1}$ A. AKHMEDOV, Doctor of Technical Sciences, Professor Department, Uzbekistan.

${ }^{2}$ Sh. AHMEDOV, Doctoral student, Tashkent Institute of Irrigation, Uzbekistan.
} 
- применение трехколесного трактора (ЗК2) не позволяет полностью реализовать преимущества широкозахватных МТА, из-за дефицита тягово-сцепного потенциала трактора и существенного превышения допустимых норм экологического воздействия на почву.

Тогда как эти недостатки в определенной степени отсутствуют учетырехколесных тракторов. В частности уменьшение отрицательного техногенного воздействия на почву за счёт снижения (на 33\%) общей площади покрытия следами колес, уменьшения максимального давления на почву в зоне опорной площади ходового аппарата и более рациональное распределения масс агрегата по осям колес являются неполным списком преимуществ четырехколесных тракторов перед трехколесными. Однако они имеют увеличенный радиус поворота и недостаточный агротехнический просвет под балкой переднего моста, что сдерживают их применений на междурядной обработке посевов хлопчатника.

Цель исследования - разработка четырехколесного трактора с регулируемым клиренсом и проверка возможности агрегатирования с ним культиватора-растениепитателя КХУ-4Т.

Материалы и методы. Для достижения поставленной цели в СКБ «Трактор» проводятся НИ и ОКР по созданию универсально-пропашного трактора с регулируемым клиренсом [2], имеющего высокой проходимости и по результатам которых изготовлен опытный образец этого трактора под маркой TTZ-1033 [3].

Для проверки возможности применения данного трактора при междурядной обработке посевов хлопчатника и сопутствующих ему культур были проверены возможности агрегатирования с ним хлопково-овощного культиватора-растениепитателя КХУ-4Т и даны оценки на работу составленного на их базе агрегата.

Результаты и обсуждения исследований. Хлопково-овощной культиватор-растениепитатель КХУ-4Т (рис.1 и 2) предназначен для междурядной обработки посевов хлопчатника и сопутствующих ему культур (овощных культур, картофеля, кукурузы и др.), посеянных четырехрядными сеялками с междурядьями шириной 90 см.

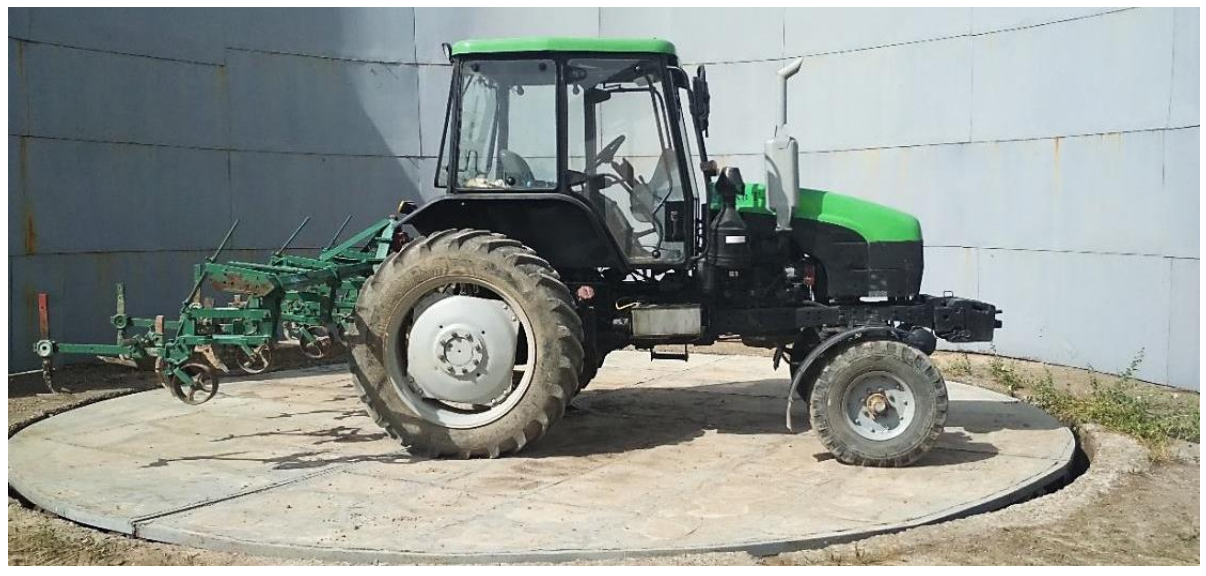

Рис. 1. Трактор с регулируемым клиренсом TTZ-1033 в агрегате с культиватором КХУ-4Т в транспортном положении 
При комплектовании различными рабочими органами культиватор КХУ-4Т должен выполнять следующие операции:

-уничтожение почвенной корки в защитных зонах рядков;

- рыхление почвы в междурядьях;

- уничтожение сорной растительности путем подрезки сорняков в почве.

При комплектовании удобрителями КХУ-4Т должен выполнять и внесении минеральных удобрений как сбоку рядков, так и в середину междурядий одновременно с нарезкой поливных борозд.

Как правило, многие из перечисленных операций совмещаются в одном проходе культиваторного агрегата за счет сочетания рабочих органов.

Культиватор КХУ-4Т является навесной машиной. Остов культиватора составляет рама, изготовленная из труб (брус) квадратного сечения и положенная на ребро. На раме установлены пять понизителей с параллелограммными четырехзвенными секциями и грядилями для расстановки рабочих органов культиватора. Крепление понизителей к брусьям производится П-образными хомутами.

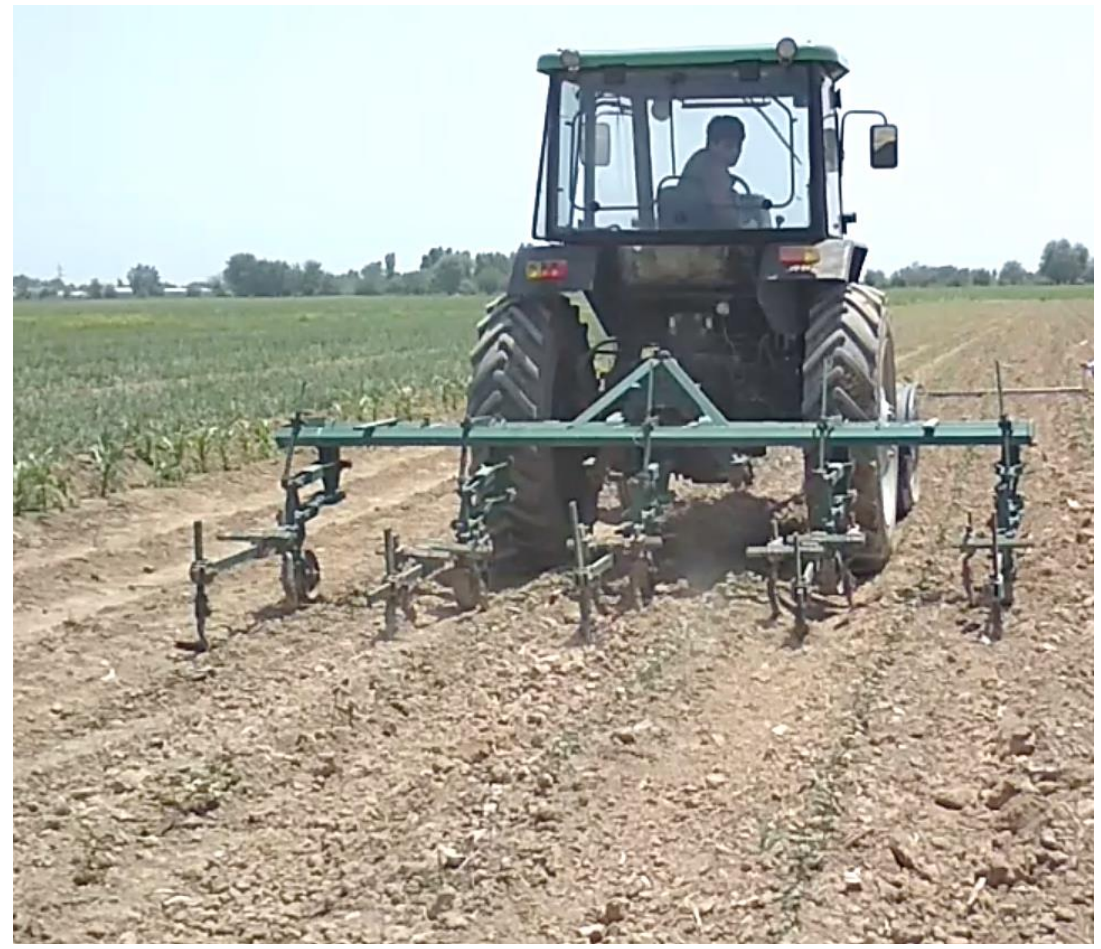

Рис. 2. Трактор с регулируемым клиренсом в агрегате с культиватором КХУ-4Т в работе

Рабочие органы крепятся на грядилях с помощью замков и квадратов, позволяющих регулировать как расстановку рабочих органов в междурядьях, так и глубину их хода в почве. 
При необходимости на раму, на кронштейнах монтируются туковысевающие аппараты. Привод аппаратов осуществляется от двух дополнительно устанавливаемых опорно-приводных колес, на осях которых монтируются приводные механизмы представляющих собой цепные передачи в корпусах, закрепленных с помощью хомутов к раме культиватора.

К раме через переходные детали крепится кронштейн автосцепки СА-2.

Все грядили имеют параллелограммную систему хода комплекта рабочих органов по вертикали, опорные колеса, предотвращающие перезаглубление рабочих органов и подъемные штанги с пружинами для увеличения давления при недостаточном заглублении рабочих органов.

После навески культиватора КХУ-4Т на трактор были проверены переводы машины из транспортного в рабочее положение и наоборот.

При проверке работы агрегата для междурядной обработки посевов хлопчатника, составленного на базе трактора с регулируемым клиренсом (в высококлиренсном положении) и культиватора КХУ-4Т не было отмечено опасного сближения элементов трактора и культиватора.

Агрегат комплектуется и управляется одним трактористом без помощи вспомогательных рабочих и грузоподъемных средств.

Для проверки работы агрегата в полевых условиях заранее была определена ширина поворотной полосы и схема движения агрегата на поле.

Учитывая то, что культиватор КХУ-4Т навесной, ширину поворотной полосы агрегата (рис.3), совершающий на концах гона петлевые повороты вычисляют согласно работе [4] по формуле

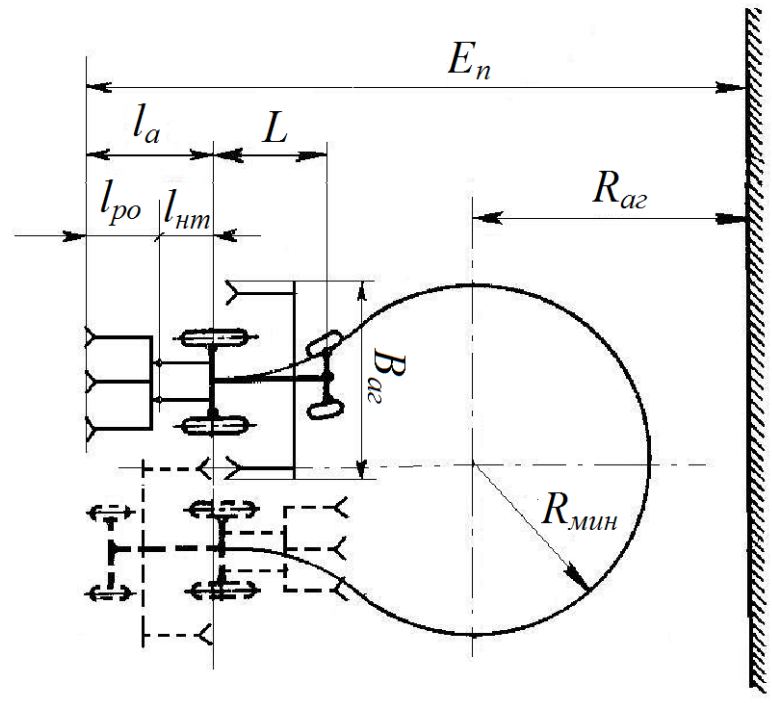

Рис. 3. Схема движения на поворотной полосе агрегата, составленного на базе трактора с регулируемым клиренсом и культиватора КХУ-4Т 


$$
E_{n}=2,8 R_{\text {мин }}+0,5 B_{a 2}+e
$$

где $E_{n}$ - ширина поворотной полосы, м;

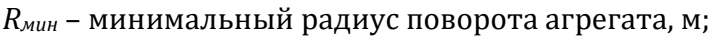

$B_{a z}$ - кинематическая ширина агрегата, м;

$e$ - длина выезда агрегата, для навесных агрегатов $e=(0,3-0,6) l_{a}$, м;

$l_{a}$ - длина агрегата (расстояние по прямой между центром агрегата и последним рядом его рабочих органов), м.

Трактор с регулируемым клиренсом имеет две направляющие колеса и в соответствии с работой [5] определяем для навесных машин минимальный радиус поворота агрегата, совершающего петлевой поворот на конце гона

$$
R_{\text {мии }}=R_{n}+\frac{K_{n}^{2}}{24 R_{n}^{3}},
$$

где $K_{n}$ - показатель поворотливости;

$R_{H}$ - номинальный радиус поворота агрегата, м.

Показатель поворотливости колесного трактора определяется скоростями поворота и отклонения направляющих колес следующей зависимостью

$$
K_{n}=L \frac{V_{\text {пов }}}{V_{\text {отк }}},
$$

где $L$ - расстояние между осями колес, ограничивающих опорную поверхность трактора, м;

$V_{\text {пов }}$ - скорость поворота направляющих колес, м/с;

$V_{\text {отк }}$ - скорость отклонения направляющих колес, рад/с.

Номинальный радиус поворота для колесных тракторов с двумя направляющими колесами определяется выражением

$$
R_{n}=\frac{L}{\operatorname{tg}\left(\alpha_{c p}-\delta_{1}\right)+\operatorname{tg} \delta_{2}},
$$

где $\alpha_{c p}$ - среднее значение угла отклонения колес, градус;

$\delta_{1}, \delta_{2}$ - углы бокового увода соответственно передних и задних шин, градус.

На основе расчетных данных и сопоставлении их с экспериментальными данными определена техническая характеристика агрегата, которая приведена в таблице 1.

\section{Таблица 1}


Техническая характеристика трактора с регулируемым клиренсом в агрегате с культиватором КХУ-4Т

\begin{tabular}{|c|c|c|}
\hline $\begin{array}{c}\text { № } \\
\text { П/П }\end{array}$ & $\begin{array}{c}\text { Наименование показателей (параметров), раз- } \\
\text { мерность }\end{array}$ & $\begin{array}{l}\text { Значение показателей } \\
\text { (параметров) }\end{array}$ \\
\hline 1 & Ширина захвата, м & 3,6 \\
\hline 2 & Рабочая скорость, км/ч & $5-6$ \\
\hline 3 & Транспортная скорость, км/ч & До 15 \\
\hline 4 & Число обрабатываемых рядов & 4 \\
\hline 5 & $\begin{array}{l}\text { Габаритные размеры агрегата, мм } \\
\text { а) в рабочем положении: } \\
\text {-длина } \\
\text {-ширина } \\
\text {-высота } \\
\text { б) в транспортном положении: } \\
\text {-длина } \\
\text {-ширина } \\
\text {-высота }\end{array}$ & $\begin{array}{l}6375 \\
3900 \\
2850 \\
6325 \\
3900 \\
2850\end{array}$ \\
\hline 6 & Дорожный просвет, мм & 325 (по носку наральника) \\
\hline 7 & $\begin{array}{l}\text { Эксплуатационная масса агрегата, кг (180кг } \\
\text { технологического груза) }\end{array}$ & 5090 \\
\hline 8 & $\begin{array}{l}\text { Распределение эксплуатационной массы агре- } \\
\text { гата по осям трактора, кг } \\
\text {-на переднюю ось } \\
\text {-на заднюю ось }\end{array}$ & $\begin{array}{l}1650 \\
3480\end{array}$ \\
\hline 9 & $\begin{array}{l}\text { Минимальный радиус поворота агрегата при } \\
\text { заторможенном внутреннем (правом) } \\
\text { ведущем колесе трактора, м. } \\
\text { - по крайней наружной точке агрегата } \\
\text { - по следу наружного колеса трактора }\end{array}$ & $\begin{array}{l}4,42 \\
3,6\end{array}$ \\
\hline 10 & $\begin{array}{c}\text { Колея трактора, мм } \\
\text { - передних колес } \\
\text { - задних колес } \\
\end{array}$ & $\begin{array}{l}1820 \\
1810\end{array}$ \\
\hline 11 & Способ агрегатирования & $\begin{array}{l}\text { Единичное навесное орудие. } \\
\text { Задняя навеска через авто- } \\
\text { сцепку СА-2. }\end{array}$ \\
\hline 12 & $\begin{array}{l}\text { Обслуживающий персонал при составлении аг- } \\
\text { регата }\end{array}$ & 1-тракторист \\
\hline 13 & $\begin{array}{l}\text { Коэффициент использования грузоподъемно- } \\
\text { сти шин; } \\
\text { а) Задних колес 15,5R38 по ГОСТ 7463-2003 } \\
\text { б) Переднего колеса 9-16 по ГОСТ 7463-2003 }\end{array}$ & $\begin{array}{l}0,82 \\
0,5\end{array}$ \\
\hline 14 & $\begin{array}{l}\text { Продольная координата центра масс агрегата } \\
\text { при транспортном положении, мм }\end{array}$ & 436,8 \\
\hline 15 & $\begin{array}{l}\text { Коэффициент запаса продольной устойчивости } \\
\text { агрегата }\end{array}$ & 0,20 \\
\hline 16 & $\begin{array}{l}\text { Расстояние от опорной поверхности до нижней } \\
\text { кромки брусьев рамы культиватора в зоне про- } \\
\text { хождения рядков, мм }\end{array}$ & 780 \\
\hline
\end{tabular}

В ходе исследовании не выявлены замечания по агрегатированию культиватора КХУ-4Т с трактором с регулируемым клиренсом.

Вывод: Трактор TTZ-1033 агрегатируется с задненавесным хлопково-овощным культиватором КХУ-4Т без замечания. 


\section{References}

[1] Ахметов А.А. Передние мосты универсально-пропашного трактора хлопкового назначения. - Ташкент: Фан, 2014. - 176 с.

[2] Патент UZ FAP 00903. Универсально - пропашной трактор / Ахметов А.А., Усманов И.И., Саидаминов С.С., Ахмедов Ш.А. - 2014. - Бюл., №5.

[3] Ahmetov A., Ahmedov Sh. Experimental sample of power means for cultivation of the cotton on six-row system // Proceedings of the III Tashkent International innovation forum. TIIF - 2017. From Innovative Ideas to Innovative Economy. - Tashkent, 2017. - P. 259-263.

[4] Фортуна В.И. Эксплуатация машинно-тракторного парка. - М.: Колос, 1979. 375 c.

[5] Анилович В.Я., Водолажченко Ю.Т. Конструирование и расчет сельскохозяйственных тракторов. - М.: Машиностроение, 1976. - 456 с. 


\section{SUBSTANTIATION OF RELIABILITY OF THE FIBER REINFORCED CONCRETE SUPER- STRUCTURE DESIGN FOR HIGH-SPEED RAIL LINES IN THE CONDITIONS OF THE REPUBLIC OF UZBEKISTAN}

E. Yakhshiev ${ }^{1}$, Z. Mirzaeva ${ }^{2}$

\section{Abstract}

The purpose of the research is the solution of scientific and applied problems for substantiation of possibility of application of dispersion-reinforced concrete in the construction of superstructures on high-speed highways. Thus, the use of fiber allows to improve the resource characteristics and durability of concrete superstructures on high-speed highways in the conditions of dynamic loads, regional climate peculiarities of the Republic of Uzbekistan. A reasonable use of particulate-reinforced concrete in the superstructure contributes to a significant improvement in concrete properties when working in tension and bending, and in many ways helps to solve the issue of ensure the crack resistance of structures under conditions of significant dynamic loads. The consideration of complex factors to solve applied problems

Keywords: prticulate-reinforced superstructure, fiber, high-speed railway, safety, durability, reliability, fracture dynamics, rolling stock, technology of concreting.

According to the results of numerous studies devoted to the practice of design, construction and operation of transport facilities, including bridges and tunnels on the network of railways and motor roads, effective maintenance of their operational status and safe operation during the scheduling service life is possible provided that the integrated management of their reliability is performed throughout the life cycle of a facility. [3]

$$
H=f\left(H_{n}, H_{c}, H_{\ni}, T_{\ni}\right),(1)
$$

where $H$ - reliability of the facility, $H_{n}$ - design reliability, $H_{c}$ - technological reliability, $H_{3}$ - operational reliability; $T_{\ni}$ - operating time (service life).

The reliability parameters, determined depending on the functional properties of buildings and structures at all stages of the life cycle, are values dependent on random events. These events, according to a number of studies, are due to formation of defects, formation of failure, and transition of a structure to a non-operable condition. $[2,6,13]$

In the general form, the reliability parameters can be presented by:

$$
\left.\begin{array}{l}
X_{1}=f\left(\alpha_{11}, \alpha_{12} \ldots \alpha_{1 m}\right) \\
X_{2}=f\left(\alpha_{21}, \alpha_{22} \ldots \alpha_{2 m}\right) \\
\ldots \ldots \ldots \ldots \ldots \ldots \ldots \ldots \ldots \ldots . . . \ldots \ldots \ldots \ldots \ldots \ldots \\
X_{n}=f\left(\alpha_{n 1}, \alpha_{n 2} \ldots . . \alpha_{n m}\right)
\end{array}\right\},
$$

where

${ }^{1}$ Elbek YAKHSHIEV, Assistant, Tashkent Institute of Railway Transport Engineers, Uzbekistan.

2Zamira MIRZAEVA, Assistant, Tashkent Institute of Railway Transport Engineers, Uzbekistan. 
$X_{n}$ - the reliability parameters to be determined against the functional properties of structures and types of safety.

$\alpha_{11}, \alpha_{22}, \alpha_{n m}$ - random variables.

In this connection, in general terms, reliability is a complex integral index of a set of functional characteristics that determine the safety of structures during the entire service life [15].

$$
\int_{0}^{S}\{H\}=\int_{0}^{S}\left\{\begin{array}{llll}
X_{11} & X_{12} & X_{1 i} \ldots & X_{1 m} \\
X_{21} & X_{22} & X_{2 i} \ldots & X_{2 m} \\
X_{i 1} & X_{i 2} & X_{i 3} \ldots & X_{i m} \\
X_{n 1} & X_{n 2} & X_{n 3} \ldots & X_{n m}
\end{array}\right\},
$$

where

$H$ - reliability.

$S$ - operating life of the structure.

The variety of factors determining the reliability of a bridge, including infrastructure, functional requirements, design features, operating conditions, including climatic, engineering-geological ones, seismic impacts, necessitate formalization of all significant reliability indicators that ensure the safe operation of a structure.

Determining such reliability indices is associated with the solution of a set of scientific problems. Thus, for bridges operated on high-speed rail lines, dynamic parameters and other features associated with the movement of high-speed trains through artificial structures are significant parameters [14].

For structures differing in purpose and features of work, the set of parameters characterizing reliability is different. The life characteristics of structures are also different depending on the material, the design features and their operational scheme, the assigned service life.

According to studies of various authors in the field of bridge structures reliability, a bridge is a complex system. On the one hand, the system consists of structural elements that differ in terms of design and operating conditions, and on the other hand it ensures the unity of operational, functional requirements as a result of the joint operation of the elements.

And its reliability will be determined by the reliability of its individual structural units.

$P=\prod^{n} P_{i}$

where $n$ - the number of consecutive elements from the main structures,

$P_{i}$ - the probability of failure-free operation of each element.

The rating of the bridge reliability indices is a complex engineering task for solving even within a single type of structures. Mainly, this is due to the complexity of determining the failure criterion attributable to the variety of factors that determine the bridge reliability and the variability of the features characterizing the system and determining the occurrence of random events. 
For this reason, many researchers establish failure criteria and rate reliability indices of certain types of bridges by factors of life reliability of structures and materials associated with individual stages of the life cycle, as well as with operating conditions. Such studies include works, etc. $[10,11]$

Studies in the field of reliability of reinforced concrete structures have significantly expanded the boundaries of the possible use of reinforced concrete bridges on the railway network. Major statistical material that allows analyzing the reasons for occurrence and development of such defects determines the possibilities for improving the properties of reinforced concrete bridge structures and prolonging their service life in different operating conditions.

In the period from March 2013 to October 2015, a survey was conducted on a network of railways with normal and high-speed operation situated in the Republic of Uzbekistan, and the causes of defects in reinforced concrete bridges were analyzed. It was found that the most typical defect associated with the operating conditions of superstructures, according to the frequency of occurrence, are cracks in $85 \%$ of cases. Depending on the location and the degree of development in the structure, they reduce the load capacity and durability of superstructures, and bring the structure into a non-operable condition. These circumstances complicate the operational characteristics of the railways, determining the need to reduce the speed of train movement in certain sections down to $25 \mathrm{~km} / \mathrm{h}$. On a network of high-speed rail lines, the development of cracks is of progressive nature, which is aggravated by climatic and seismic impacts typical for the region.

In connection with the transition to high-speed traffic, the question of the reliability of reinforced concrete superstructures acquires extreme urgency due to the need to develop requirements for bridges that provide specified operating speed rates for railways $[8,9,12]$.

As the world experience in the construction and operation of high-speed rail lines in similar conditions shows, the use of fiber reinforcement in structural elements allows minimizing the formation of defects caused by various impacts, including those associated with dynamics from the rolling stock. Also, there are laboratory test data confirming a significant improvement in the life performance of fiber reinforced concrete structures that ensure the extension of their life.

In such a case, the formation of a crack in a superstructure with the opening up to the limit value $\left[\Delta_{c r}\right]_{n p}$ at the train speeds $V_{\max } \leq 300 \mathrm{~km} / \mathrm{h}$ due to a combination of random events is in fact a failure of the superstructure design that puts in a non-operable condition,

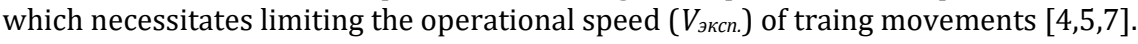

Furthermore, it is reasonable to establish the structure failure through the maximum crack opening width $\Delta_{c r f b}$, which, being reached, causes reducing the design superstructure reliability $H_{n}$ in terms of functional and life indices.

Then the failure criterion will be as follows:

$$
\left[\Delta_{c r}\right]_{n p} \geq\left\lfloor\Delta_{c r f b}\right\rfloor,
$$

where

$\left[\Delta_{c r}\right]_{n p}$ - limit width of a crack opening,

$\Delta_{c r f b}$ - maximum width of a crack opening. 


$$
\Delta_{c r f b} \geq \varphi_{1} \cdot \varphi_{2} \cdot \varphi_{3} \cdot \psi_{s} \frac{\sigma_{s}}{\mathrm{E}_{s} \cdot 10^{2}} \cdot l_{s}
$$

where

$\varphi_{1}-$ load action short duration factor,

$\varphi_{2}$ - renforcement metal deformed section factor,

$\varphi_{3}$ - flexural member factor,

$\psi_{s}$ - line-distributed load,

$\sigma_{s}$ - normal stress,

$E_{s^{-}}$concrete modulus of elasticity.

A research work to justify the characteristics of fiber-reinforced concrete superstructure $L=66 \mathrm{~m}$ for high-speed rail lines in the conditions of the Republic of Uzbekistan has been carried out at the Dridge Department of St. Petersburg State Transport University in cooperation with the design organization Consulting \& Information Center for Modern Bridge Technologies LLC. As a result of mathematical modeling, it was established that the reliability of such structures is related to the probability of forming a normal crack to the axis of the superstructure with opening to $\Delta_{c r f b}=0.011 \mathrm{~mm}$.

It was found that the use of a fiber-reinforced concrete structure completely makes it possible to fully eliminate the occurrence of diagonal cracks caused by the action of the shear force and reduce the maximum crack opening $\Delta_{c r f b}$. by a factor of two in comparison with the limiting value of opening for normal pre-stressed reinforced concrete, regulated [1].

Also, in the course of mathematical modeling the following effects, which increase the structural $\left(H_{n}\right)$ and technological $\left(H_{c}\right)$ reliability of the superstructure and determine the effectiveness of the use of fiber-reinforced superstructures on high-speed rail lines in the Republic of Uzbekistan were obtained.

The first effect. Reduction of the height of the compression area of the $X$ superstructure.

It is established by methods of calculation for ultimate limit states. In many respects, it is determined by an increase in the design resistance of the superstructure structural material and, consequently, the breaking bending moment in the case of fiber reinforcement, respectively. Thus, $R_{b}<R_{b f} M_{f}>M$

where,

$R_{b-\text { design concrete resistance; }}$

$R_{b f}$ - design fiber-reinforced concrete resistance;

$M_{f}$ - breaking bending moment of the fiber-reinforced concrete superstructure;

$M$ - breaking bending moment of the reinforced concrete superstructure;

The scheme for determining the height of the compression area is shown in Figure 1. 

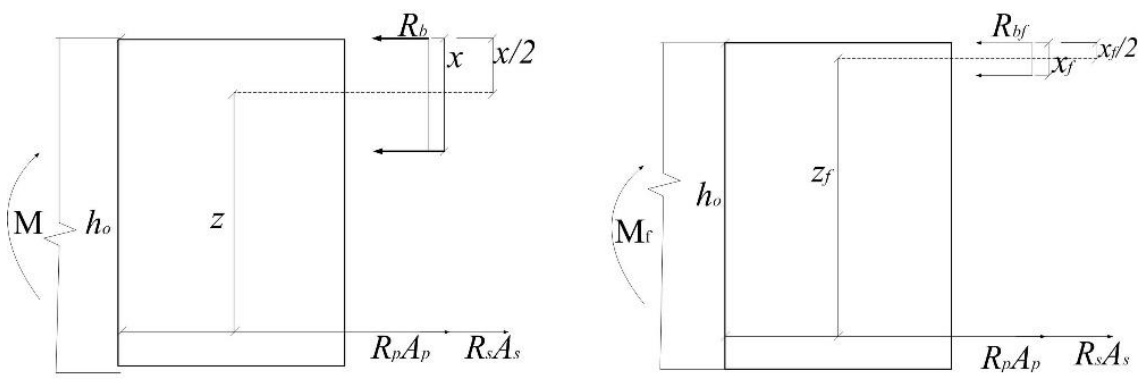

Fig. 1. Scheme for determining the height of the compression

area of ordinary and fiber-reinforced concrete

Improvement of the strength characteristics of a material, including the $R_{b f}$ design fiberreinforced concrete resistance allows providing effective constructive and technological solutions.

When developing the structural solutions of a superstructure, the effect allows:

- reducing the material consumption of the structure, ensuring the best technical and economic parameters of the superstructure:

- reducing the thickness of the walls of the fiber-reinforced concrete superstructure framing to $b=250 \mathrm{~mm}$;

- reducing the load caused by the structure dead weight by $15 \%$;

- reducing the consumption of reinforcement metal and concrete.

In addition, the effect makes it possible to improve the superstructure operation by increasing the strength of the superstructure plate deck under the action of shock dynamic impacts from the rolling stock.

The second effect: increase in the crack resistance, rigidity, durability of a superstructure.

It is established by calculation methods for the service limit states for the formation and width of the crack opening in the superstructure, as was mentioned above. According to the authors, it is the main one from the perspective of forming the reliability of a fiberreinforced superstructure. Under conditions of considerable dynamic loads, it is essential from the perspective of forming the rigidity of the superstructure and seismic load accommodation. Minimizing the processes associated with the formation of cracks provides the construction life characteristics, which ensures the $T_{3}$ useful life of the structure.

The third effect: increase in the operational reliability of the transmission zones of concentrated effects instead of local reinforcement.

Such areas include the anchoring points of the longitudinal high-strength reinforcement $(1 ; 2)$, the fracture zones of the high-strength reinforcement $(3)$, the anchoring points of the clamps, the anchoring points of the transverse high-strength reinforcement shown in Figure 2. 

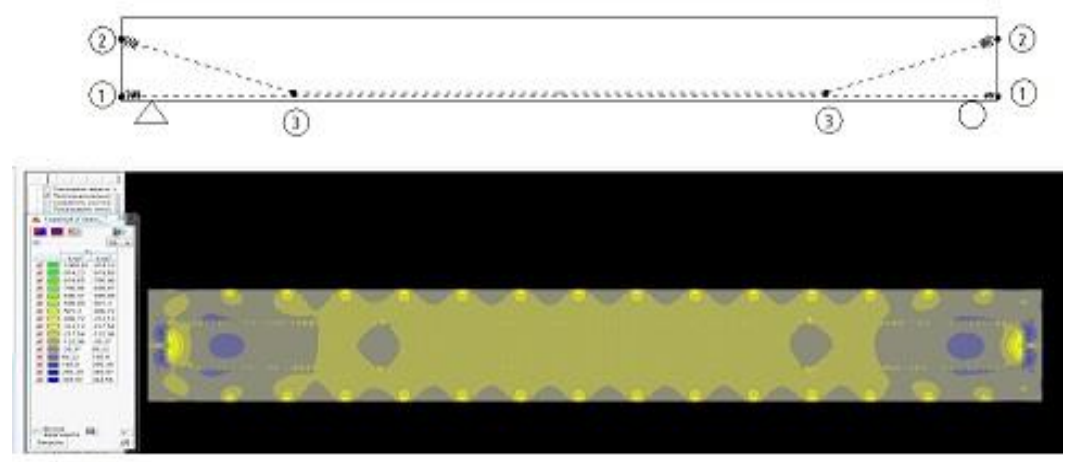

Fig. 2. The scheme for determining the cracks and the stress field $\sigma$ in the transmission zones of concentrated loads along the superstructure plate deck

Using the effect in designing allows:

- improving the design of the nodes of concentrated forces transmission;

- increasing the technological efficiency of constructing a superstructure by reducing the time of construction, improving the quality of concrete work thank to the absence of need for concreting high-density reinforced elements.

When carrying out the justification of constructive solutions of a fiber-reinforced concrete superstructure, requirements for ensuring the reliability at various stages of the life cycle were developed. They were reflected in the development of the regulatory document 'Procedure for the Design and Construction of a Fiber-Reinforced Concrete Superstructure under the High-Speed Rail Line in the Conditions of the Republic of Uzbekistan', which was adopted on the network of railways in Uzbekistan.

\section{Conclusions:}

As a result of the work, the theoretical scientific problem on justifying the reliability of fiber-reinforced concrete structures intended for the use on high-speed rail lines in the conditions of the Republic of Uzbekistan was solved.

The scientific and applied nature of the task is associated with the identification of the advantages of fiber-reinforced concrete structures and the development of practical recommendations for the design and construction of such structures.

The solution of the problem allows increasing the efficiency of operation of high-speed rail lines, improving the life characteristics of superstructures of fiber-reinforced concrete bridges, improving their reliability and durability. The prolongation of the service life and the increase in the periods between repairs make it possible to ensure the economic efficiency of such structures in comparison with structures that are not fiber-reinforced ones.

\section{References}

1. Avirom L.S. Reliability of Prefabricated Buildings and Structures / L.S. Avirom // Leningrad: Stroyizdat, Leningrad Branch, 1971. - 216 p.

2. Begam L.G. Reliability of Bridge Crossings Over Water Courses / L.G. Begam, V.Sh. Tsypin // M: Transport, 1984. - 252 p.

3. Yermolaev N.N. Reliability of the Foundations of Structures / N.N. Yermolaev, V.V. Mikheev, L // Leningrad: Lengrad Branch, 1976. - 152 p. 
4. Iosilevsky L.I. Industry Fabricated Reinforced Concrete Bridge Superstructures (Design and Calculation Methods) / L.I. Iosilevsky, A.V. Nosarev, V.P. Chirkov, O.V. Shepetovsky // Moscow: Transport, 1986- $216 \mathrm{p}$.

5. Kudzis A.P. Assessing the Reliability of Reinforced Concrete Structures / A.P. Kudzis // Vilnius: Mokslas, 1985. - $156 \mathrm{p}$.

6. Novak Yu.V. Pertains to Assessing the Reliability of the Calculation Method for the Sloping Sections of Reinforced Concrete Structures. // Reliability of Bridge and Tunnel Structures. Collection of the MADI Scientific Papers. M.: MADI, 1986. - pp. 23 - 26.

7. Osipov V.O. Maintenance, Reconstruction, Strengthening and Repair of Bridges and Pipes / V.O. Osipov, Yu.G. Kozmin, A.A. Kirsta, E.S. Karapetov, Yu.G. Ruzin; Ed. by V.O. Osipov and Yu.G. Kozmin // Moscow: Transport, 1996. - 471 p.

8. Guidelines for Determining the Load Capacity of Reinforces Concrete Superstructures of Railway Bridges / Ministry of Railways. M.: Transport, 1989. -127 p.

9. Smirnov V.N. Management in Bridge Construction / School for Advanced Studies and Refresher Training / V.N. Smirnov, S.V. Chizhov // St. Petersburg: SPb., 2011. - 42 p.

10. Smirnov V.N. Special Aspects of High-Speed Movement of Railway Express Trains on Bridges / V.N. Smirnov // St. Petersburg: SPb, 2015. - 57 p.

11. SNiP 2.05.03-84 Bridges and Pipes M.: State Committee of the Russian Federation for Construction and Housing and Utility Complex, State Unitary Enterprise Centre of Construction Design Products, 1998. - $214 \mathrm{p}$.

12. Chestnoy V.M. Reinforced Concrete Bridges: Temperature and Reliability / V.M Chestnoy // M: Transport, 1991. - $135 \mathrm{p}$.

13. Chizhov S.V. Reliability of Sprayed Concrete Tunnel Lining Constructed in Proterozoic Clays: Abstract, Ph.D. in Technical Sciences/ S.V. Chizhov - St. Petersburg: St. Petersburg State Transport University, 1998. - 25 p.

14. Chizhov S.V. On the Requirements for Bridges Exposed to High-Speed Movement / S.V. Chizhov, E.T. Yakhshiev // St. Petersburg: St. Petersburg State Transport University Bulletin. - 2014. - No.4. pp. 87-91.

15. PRR 2.05.03-11* 'Bridges and Pipes'. 


\section{LAW}

THE PECULIARITIES OF INDIVIDUALS WHO COMMIT VIOLENT OFFENSES IN THE FAMILY

\section{${ }^{1} \mathrm{~A}$. Murodov}

\section{Abstract}

The article outlines the criminological description of individuals who committed violence in the family, the demographic data of the offender, his inner spiritual world, needs, attitudes, emotional irony, induvidial features, and the level of criminogenism.

Key words: individual who commit violent offense in the family, social and demographic characteristics, offender's personality, criminogenicitical degree of a person.

It is known that, the problem of socially dangerous and guilty actions of person is investigated in the subject of criminology. Indeed, the scientific study of the perpetrators has its essence and meaning. When criminality is investigated as a social phenomenon, the offender's personality and its characteristics are also studied. Therefore, in order to investigate the socially-dangerous and unlawful behavior of individuals who commit violence in the family, it is essential to identify their non-social and criminological characteristics.

A Socio-demographic characteristic related to a person who has committed a crime in a domestic violence is important in preventing such offenses.

Because it is possible to examine all the characteristics of the crime by investigating the socio-demographic characteristics of those criminals. Generalizing these socio-demographic signs, it is possible to develop important criminological findings on the basis of the study of socio-demographic characteristics of individuals who committed crimes in a particular region and period.

In the psychological study of the criminal, it is necessary to analyze it in the connection with social environment. Because, criminal conduct does not make a, but rather their interrelation ${ }^{2}$. The impact of the social environment on criminal behavior is a complex feature and it provides accurate information on the problem being studied.

When analyzing personal materials from the investigative jurisprudence to make a realistic conclusion about the individuals who committed the crime during the investigation, the majority of these categories were those who do not have a high level of education, previously convicted, temporarily unemployed addicted to alcohol and drugs, non-social behavior.

Individuals who have committed violence in the family have $54.3 \%$ cases of deliberate infliction of injuries, $9.1 \%$ deliberate killing, $12.5 \%$ involvement of a juvenile in non-social activities, $6.1 \%$ abusive method of sexual exploitation $5.4 \%$ slander, $4.7 \%$ of torture, $2.1 \%$ rape, $1.0 \%$ put in danger, $3.2 \%$ insulting, and $1.6 \%$ self-killing.

When the level of knowledge of the offenders is examined, $5 \%$ of them have high education, $26 \%$ secondary special, $66 \%$ secondary, and $3 \%$ non-complete secondary education.

\footnotetext{
${ }^{1}$ Alisher MURODOV, Doctorate of Postgraduate Education Faculty of Ministry of Internal Affairs of the Republic of Uzbekistan.

${ }^{2}$ Dushanov R. X. Psychology of criminal: Manual-T., 2011. -p.6.
} 
It should be noted that the classification of the individuals who have been abused in the family by the level of knowledge is not the same for different types of crimes in different periods in the regions. For example, often family violence occurs by the people who have no high education, but economic crimes are higher in those with higher education.

There is a tendency towards committing a crime in the same category of people. According to our research $50 \%$ of all murders and bodily injuries are related to those who are involved in family violence.

In a number of criminological studies, individuals who have committed crimes have been reported to be highly unstable. Professor I.Ismailov sates that: "The lack of knowledge, the low level of culture, the more intense narrowness and the humiliation of personality, the sophistication of morality, will be cause for the development of personality and selfishness." 1

The low level of knowledge of the individual, the inadequate awareness of the individual, the inability to understand the consequences of his actions, and the non-self-governing nature of his actions are crucial to the offense. These people will eventually do so without thinking of crimes against the life and health of the individual to fulfill their violent intentions.

During the investigation of the perpetrator, it is necessary to pay attention to the inner spiritual world, needs, tendencies, emotional irresponsible level, and human rights of the offender. As long as the above-mentioned features are not fully studied, it is inappropriate for preventive measures to prevent crime.

The lawyer, Abdurasulova Q.R. states that the general definition and the statistical study of the persons who have committed crimes can help to identify the characteristics of certain categories of people and to take measures to prevent crime ${ }^{2}$.

Scientists L.M. Prozumanov and A.Shesler say that it is necessary to study the criminological types of offenders by nature 3 . While learning personality, social-psychological traits, their nature, through the inner world of the offender, allow them to identify the cause of their crimes.

Analyzes show that most offenders have learned to drink alcohol from young ages and under the influence of this situation did variety of offenses. Individuals in the same category are more likely to commit crimes, and should be aware of the various types of bodily injury to the individual's life and health as part of his offenses.

It should be noted that in the case of violent offenders in the family, the lack of compassion or the aggressiveness of their conduct is evident in the conduct of various forms of violence. Persons of this category are mainly violent, persecuted, violent individuals.

The behavior of the violent in the family is characterized by the presence of rudeness and the socio-psychological traits that are characteristic of their psychology. They commit various offenses against the individual within the framework of family

Frustration, feeling of excitement, jealousy, and rudeness, no self-control, and misconduct are often characteristic for the psychology of offender. People of this category often do

\footnotetext{
${ }^{1}$ Ismailov I. Organized Crime: Theory and Practice Issues. -T., 2005. -p. 78.

${ }^{2}$ Abdurasulova Q.R. Criminal and Criminological Issues of Female Crimes: doc. of law sciences. Diss. 2006. - p.75.

${ }^{3}$ Prozumentov LM, Sesler AV Criminology.. - Krasnoyaryask: 1997.-C. 107-110; Kirillov SI, Solodovnikov SA Investigation of robberies in the system of criminal violence. -FROM. Molensk: 1997.-p. 120.
} 
not care about the consequences of their actions, and they do not hesitate to commit suicide under its influence.

Such individuals generally try to endanger the possession of any victim, and to respond violently to the victim's actions. The level of a person's criminogenic demonstrates high possibility of his crimes. Such conduct can also cause offense in respect of their relatives.

Research has shown that the specific mental properties of individuals who have committed a crime in situations of family life are regulated by certain unusual circumstances in life and are manifested in specific actions. Those who are of this category more likely to commit suicide whenever there is a problem or conflict in the family life.

On the basis of the analysis, it can be concluded that family prosecution has resulted in a criminal offense mainly resulting in reprisals by the victim or trying to put their own interests among the family members. Another factor influencing personal injury is that the perpetrator does not understand his / her actions and consequences.

Another factor influencing personal injury is that the perpetrator does not understand his / her actions and consequences.

In summary, it can be said that are those who are inclined to commit offenses in the family, are persons who are aggressive, have a high criminogen level, and have a bad relationship with family members and others in the family life and people who do not have high moral qualities. 
REGISTRATION OF SOME NON-TRADITIONAL MARKS IN SOME FOREIGN COUNTRIES (legislation and practice revision)

Z. Babakulov ${ }^{1}$

Abstract

In this article it will be analyze same non-traditional marks by the legislation of foreign countries.

Key words: trademark, non-traditional marks, TRIPS, EC Directive.

A trademark is a type of industrial property is distinct from other forms of intellectual property, which is used to distinguish a business or services. Conventionally, a traditional trademark comprises a name, word, phrase, logo, symbol, design, image or a combination of these elements. However, there are certain other non-traditional trademarks which have gained prominence in recent times and include sound marks, odour marks, colour marks, shapes and taste marks. Afterwards we will look through some of non-traditional marks as a regulation by the legislative some countries for regulation trade marks.

In many countries such as USA, UK, South Korea, Uzbekistan, Italia, Australia and other countries for regulation of trade marks prescribed legislative regulation non-traditional marks. By the legislation of trademark law of Italia Chapter I Art. 16 prescribed to registration non-traditional marks as a trademark by the article any new sign which can be represented graphically, particularly words, including personal names, designs, letters, numerals, sounds, the shape of goods or of their packaging, color combinations or tonalities, provided that they are capable of distinguishing the goods or services of one enterprise from those of other enterprises may be registered as a trademark. In Australia by the law of Trade Marks Act Part 2 (1) legislative protection of non-traditional marks prescribed in aspect of packaging, shape, colour, sound or scent. In US, the Lanham Act's definition of "trademark" encompasses non-traditional marks by not excluding them. It includes any word, name, symbol, or device, or any combination thereof that identifies and distinguishes the goods and services of one person from those of another and indicates their source. The Supreme Court has made it obvious that trademark might include anything that is capable of having some meaning. On the other hand, the UK Trademark Act in Section 1(1) defines trademark as any sign capable of distinguishing goods and services of one undertaking from that other undertakings. A trademark may in particular consist of words, designs, letters, numerals, or shape of other goods or packaging.

Thus unlike the US position, there is a restriction in UK as to what could possible constitute a trademark ${ }^{2}$. The Article 15.1 of TRIPS Agreement makes a requirement that any sign or combination of signs can be registered as a trademark although it might required that the mark be visually perceptible. Under EU law, a sign must capable of being presented graphically in addition to which it must be clear, precise, self-contained, easily, accessible, intelligible, durable, objective and not deprive the trade or the public of signs that the directive or regulation imlies should be free to all ${ }^{3}$. In Germany by the Trademark law 3(1) prescribed as a any signs, particularly words, including personal names, designs, letters, numerals, sound marks, three-dimensional configurations, including the shape of

1Zafar BABAKULOV, Science researcher of Tashkent State University of law, Uzbekistan.

\footnotetext{
2 Michaels Amanda, A practical Guide to Trademark Law (Sweet and Maxell, London), 2002, p. 10.

${ }^{3}$ Article 2, EC Council Directive 89/104/EEC of 21 December 1988 to approximate the laws of the member state relating to trademarks; Article 4, EC Council Regulation No. 40/94 of 20 December 1993 on the Community Trade Mark.
} 
goods or their wrapping as well as other packaging, including colors and combinations of colors, which are capable of distinguishing the goods or services of one undertaking from those of other undertakings may be protected as trade marks. In India, Section 2(1) (zb) of the Indian Trademarks Act specifies that any mark which is distinctive i.e. capable of distinguishing goods and services of one undertaking from another, and capable of being represented graphically can be a trademark.

Registration of a trademark helps to instill consumer and prevent confusion about the source of products sold under a trademark. Consumers rely on trademarks in most cases it is difficult to inspect a product quickly and cheaply to determine its quality 1 .

The greatest need for using non-traditional trademarks arises because market-savvy companies want to design and advertise their products in such a manner that appear to the consumer's aesthetic sense. However, while a non-traditional mark also entitled to protection as much as a conventional trademark, there are certain underlying problems with the nature of such marks that impede the registration process.

According to Article 2 of the European Directive and as under the UK trademarks Act, 1994 , the three main requirements for being registered as a trademark are as follows: ${ }^{2}$

(a) The trademark should be a sign or anything that can convey information.

(b) The sign should be capable of distinguishing products or services or one undertaking from that of another. This is clearly a requirement of distinctiveness of trademarks.

(c) The trademark is capable of graphical representation.

Graphical representation of a trademark is undoubtedly an administrative for the purposes of precise identification in the trademarks registry. The requirement of graphical representation is thus helpful both to the traders and the people in the Registry office ${ }^{3}$. Obviously, a clear and precise graphical representations ensures that all the rights and liabilities established under the Act can be availed of 4 . Article 15 of the TRIPS, 1994 however deviates from the criteria of graphical perceptibility on the other hand.

The USA Patents and Trademarks Office (USPTO) have stated that any non-traditional can be registered as long as it distinguishes the source of the product and is not functional or descriptive ${ }^{5}$, implying that a non-traditional trademark cannot perform a utilitarian function. With respect to functionality of a given trademark, a few guidelines have been laid down by the USPTO.

Let's talk some of the non-traditional trademarks for example smell marks. Even if the product would allow consumers to access the scent, it is highly unlikely that they would use their sense of smell in order to decide which product to purchase. If the product is not selected because of its scent, its identification and the link between the scent and the manufacturer, then it fails to acquire the distinctive character necessary for it to qualify as a trademark. ${ }^{6}$

\footnotetext{
${ }^{1}$ Roth Melissa, Something old, something new, something borrowed, something blue: A new tradition in non-traditional mark registrations, Cardozo Law Review, 27 (2005) 457.

2 Torremans Paul Carl Leo, Trademark law: Is Europe moving towards an unduly wide approach for anyone to follow the example?, Journal of Intellectual Property Rights, 10 (2) (2005) 128, 131.

${ }^{3}$ Swizzels Matlow LTD's Application (No.2), (2000) ETMR 58.

${ }^{4}$ Majmudar Arka, Sandhu Subhojit and Majmudar Sunandan. The requirement of graphical representability for non-traditional trademarks, Journal of intellectual Property Rights, 11 (5) (2006) 313, $315,316$.

${ }^{5}$ McCarthy J Thomas, Trademarks and Unfair Competition, Vol 3 (West Group, ST Paul Minn), 1996, 7-92.

${ }^{6}$ ibid.
} 
It is necessary to underline smell is composed of molecules created by a stimulus, which is then detected by the human body. The complexity of the creation of the stimulus, which depends on the very molecular structures and chemical bonds involved in its development, signifies that each scent is discretely unique. In order to be detected, the molecules of a scent must get in actual contact with the potential consumer, and the further in space the latter is from the scent, the more difficult will be the detection. There is very strong evidence that most people simply cannot recoginese more than sixteen smells ${ }^{1}$. Must pay attention in the markets selling products under the smell marks it will be difficult to identify from other products.

Smell trademark is registrable in EU in one condition if the graphically representation of the mark is self-contained, durable, objective, intelligible and accessible. By the legislation of Trademark Act of Great Britain understands as a trade mark "a designation which can distinguish the goods and services"2. In this Trademark Act does not contain any restriction concerning a kind of a trade mark which protection can be presented. In the case of R v John Lewis 3 , the UK Court refused an application for 'the smell, aroma or essence of cinnamon' as a trademark for the furniture as the verbal description of a smell was not enough to make a graphical representation. But the case would have been done with reference to certain standards ${ }^{4}$. Another example the smell of fresh cut grass for tennis balls was registered as a European trademark, and the odour of beer for dart flights and of roses for tyres have been registered as trademarks in UK ${ }^{5}$. With these facts in mind, it is easier to understand that scents, because of their nature, do not possess the potential of being signs for the purpose of trademarks. Their qualitative variations caused by the everchanging environment in which they exist, coupled with the inaptitude of human beings to recognise them, make them very unfit to satisfy the primary purpose of trademarks. Scents are very likely to cause confusion amidst consumers, who will rarely be able to identify the source of the product to which the scents are applied.

It is necessary will pay attention scents have no independent identity, but rather must be associated with other memories to enable recall. We which spoke above Detection and recognition of scents depends on individual sensitivity such as physical and mental abilities, and state of an individual's health ${ }^{6}$. In addition, description of scent marks registered with the USPTO are relative vague and a court may have difficulty enforcing the scent of 'bubble gum', 'cherry', 'grape' or 'strawberry'7

It is necessary to mark that neither TRIPS nor EC Directive addresses protection for scent marks. Some countries like Australia, France, Germany, Uzbekistan do not prevent such kind of registration, leaving the options open. But some countries like Mexico, South Korea, Brazil, India, Japan etc. scent marks are neither registrable nor have the courts considered protection of scent marks under intellectual property rights regime.

\footnotetext{
${ }^{1}$ CHUROVICH, D, D, op. cit., p. 302

2 В.В.Орлова. // Патенты и лицензии №9/96. С.34.

${ }^{3}$ [2001] RPC 28.

${ }^{4}$ Bhattachearjee Sudipta and Rao Ganesh, The broadening horizons of trademark law, Journal of Intellectual Property Rights, 10 (2) (2005) 120.

${ }^{5}$ Venootschap onder Firma Senta Aromatic Marketig's Application, [1999] ETMR 429.

${ }^{6}$ Churovich Douglass, Scents, sense or cents? Something stinks in the Lanham Act, St Louis University Pubic Law Review, 20 (2001) 293.

${ }^{7}$ Londe Anne Gilson La, Cinnamon burns, marching ducks, and cherry-scented racecar exhausts: Protecting non-traditional trademarks, Trademark Reporter, 95 (2005) 773.
} 
It is necessary to underline smell marks it is group of trademarks has much in common with ${ }^{1}$. In this situations there will be a question let's admit if we entered to the market to buy goods we need for. Before eating this good smelled taste but after ate this good smelled awful. Let's see some practical examples with taste marks. In a certain case, a Netherlands corporation tried to register orange flavour for pharmaceuticals but the USPTO didn't allow it saying that is not indicate source of goods nor was it distinctive in nature. Further orange was considered to be functional in nature. The other important case in the regard is Eli Lilly's case where a company tried to register artificial strawberry flavour as a gustatory trademark for pharmaceutical products ${ }^{2}$.

In some countries (Korea, Uzbekistan, Australia) for regulation of trade marks like taste marks authorised by legislative. For example by the Trade mark Act of Australia sign includes the following or any combination of the following, namely, any letter, word, name, signature, numeral, device, brand, heading, label, ticket, aspect of packaging, shape, colour, sound or scent. In Korea by the law of Understanding the Trademark Act of the Republic of Korea sec.1.1 (1) any symbol, text, figure, three dimensional shape, color, hologram, motion, or a combination of these elements as well as any other visually perceivable thing, sound, smell or any other sign that may be identified using sensory perception, may constitute a trademark only with one conditions this scents must as long as it serves the essential function of distinguishing certain products from others.

Other type of non-conventional trademark is sound marks. Sound marks would capture the attention of internet users much more efficiently than traditional marks, which in turn have catapulted their popularity in today's commercial world. In some countries like UK doesn't specifically exclude or include sound marks as a registrable trademark. Since, the UK Act allows for the representation of a trademark by means other than graphical representations, the possibility of having sound marks. Thus, it is upon the applicant to prove that a particular sound mark can function as a trademark. In 1950, NBC successfully registered the musical notes G, E, C played on chimes as a trademark for its radio broadcasting services. Other sound trademarks include the MGM lion's roar, the song "Sweet Georgia Brown" for the Harlem Globetrotters basketball team, the spoken letter's "AT\&T" with a distinctive musical flourishing in background, and the beneficial financial services jingle. Registration of trademarks in sounds, the USPTO reports in force in the US are sounds and since 1946, there have only been 71 applications to register sounds as trademarks or service marks ${ }^{3}$.

The TRIPS Agreement, EC Directive are silent on sound trade marks. The INTA Resolution 1997 on the inclusion of sound marks as registrable marks has analysed various impediments to the registration of sound as trademarks, such as, enforceability, functionality of such sounds, problems of graphical representations and physical affixations which they say can be solved with the help of traditional trademark principles.

In Uzbekistan registration of non-traditional trademarks based on "Act of trademarks, service marks and geographical indication" 4 and the Rules of drawing, giving and consideration of the demand for registration of trade mark and service mark. By the article 3 Act of Trademark of the Republic of Uzbekistan prescribed for registration of non-traditional

\footnotetext{
${ }^{1}$ Ronning D. Taste, Smell And Sound - Future Trademarks// les Nou-velles. - 2004. - V. XXXVIV. № 1. - P. 16-21.

2 Elli Lilly's Trademark Application, [2004] EMTR 4.

${ }^{3}$ Sappherstein Michael B, The trademark registrability of the Harley-Davidson Roar: A Multimedia analysis, B C Law and Intellectual Property \& Technology Forum \& Journal, 1998, 101.

${ }^{4}$ Ведомости Олий Мажлиса Республики Узбекистан" 2001 г. N 9-10, ст. 178
} 
trademarks. Rule of registration trade mark and service mark for registration of non-traditional marks established enough requirements. By the procedure of registration all nontraditional as a sound, light and other like olfactory marks by the lagislative of Uzbekistan must present to the the Agence of Intellectual Property graphical form. For example if sound is giving for registration as a trade mark it must contain of sound characterization as well as recording musical notation or diagram frequency. If light is given for registration as a trademark announcer must show characterization of light symbol and their duration sequence fluorescence and other features.

At the last word on non-traditional marks we can say that: non-traditional marks as a trade changing very sharply. That's why legal defence and regulation of non-traditional in legislation very important question for solving it. I mean protecting of consumer's rights in the conditions of market economy. 


\section{STABILIZATION CLAUSE IN UZBEKISTAN LEGISLATION}

\section{${ }^{1}$ M. Yakubova}

\section{Abstract}

Foreign trade and investment serve as driving forces in strengthening the economy in developing countries. However, foreign investment into their territories does not mean just attraction of financial capital but also the opportunity to strengthen a stagnant economy. ${ }^{2}$ In spite of great economic and industrial potential the inflow of foreign investors in developing countries is considerably low. At present, some of the main hindrance in creating favorable investment climate in developing countries is the instability of legal regulations and the potential political risk to foreign investors. ${ }^{3}$ In developing countries such as Uzbekistan, the stabilization clause can result in restrictions that limit the States' sovereignty in enacting any new additional law on investment. This thesis describes how the form of investment law evolved in Uzbekistan and the legal regulation regarding the treatment of foreign investors with stabilization clause.

Key words: stabilization clause, foreign investment, state investment contracts, investment legislation.

The evolution of investment legislation in Uzbekistan since independence has resulted in some improvements in the economy while also creating more positive atmosphere to invite foreign investors. Policy maker believed that foreign investment would bring foreign currency, greater access to the world market, and strengthen international economic and political relationships. So far, within a short period of time, Uzbekistan succeeded in reaching some improvements in the economy while establishing closer economic relationship with other countries. However, despite the benefits, the laws have not been fully realized and present numerous challenges. To constant the legal environment for foreign investor and manages the risk from further legislative changes is one of the key point to create the favorable investment environment. Considering the given benefits and ambiguities in investment legislation there are two main weaknesses can be defining: 1) instability of the investment legislation; 2) and vulnerability of guaranties within the investment legislation.

\section{Instability of investment legislation}

Although, there are a number of privileges for foreign investors to invest in developing countries, such as low range of competition, which can increase the profit of the investor; a number of benefits provided by the hosting state, and legal protection by international agreements ( as "BIT's" Bilateral Investment Treaties or international investment agreements), foreign investor still may face the number of legal risk as tightening of legal regulation, expropriation, political risk or frequency of changes in investment legislation. ${ }^{4}$

Regarding to that, one of the important issues of Investment legislation in Uzbekistan is, that as developing country with an emerging economy, the state tends to face legal instability caused frequent amendments of investment law. ${ }^{5}$ The first investment law of 1994

\footnotetext{
${ }^{1}$ Madinabonu YAKUBOVA, Lawyer of Art and culture development foundation under the Ministry of culture of the Republic of Uzbekistan.

2 "Roman Kalis 'Legal Environment for International Investment in Uzbekistan," accessed September 4, 2015, https://www.law.muni.cz/sborniky/cofola2008/files/pdf/mps/kalis_roman.pdf

${ }^{3}$ Ibid.

4"Nick Diamond 'Foreign Investment: What? Why and How?' // Http://www.acc.com/legalresources/quickcounsel/fiwwh.cfm," accessed May 19, 2016,

${ }^{5}$ Kališ, Roman. 'Current Issues of Investing in Developing Countries.' (2009).
} 
introduce so called "grandfather clause" which gave the foreign investor the opportunity to avoid the changes of legislation passed after the registration of its company in Uzbekistan which impairs the conditions of investing. The 1994 FIL guaranteed foreign investors protection from such changes for a period of no more than ten years. The new investment law passed in 1998 fixed the period of protection from these legislative changes for full ten years. Later in 2006 another law enacted and canceled the special benefits given for particular foreign investment and put at risk some investment contracts and doubted potential foreign investors to do business in Uzbekistan.

Thus, Uzbekistan still facing the instability of law meets the need to provide the promises whether to neutralize the project from newly adopted laws, ${ }^{1}$ or to guarantee the compensation for adverse changes in domestic law.

\section{Vulnerability of guarantees within the investment legislation}

Another important aspect in Uzbekistan legislation that should be amended is the vulnerability of the benefits guaranteed and exemptions given to particular foreign investors (that meet list of requirement stated in the law).

The investment laws of Uzbekistan within specified legal benefits states about the additional exemptions that can be given to particular foreign investors, concluding the investment contract with the state. (Article 4 of The Law on Guarantees and Measures to Protect Foreign Investors' Rights.). Initially, the law regarding guarantees for foreign investors provides protection and stability of given promises, but not with additional benefits that are stated in the contract. Therefore, obscurity of additional guarantees and lack of the provision that secure those guarantees lead to the point that the investor remains weak because in cases of breach of contract additional benefits given in investment contract to the foreign investors are still stay vulnerable.

Uzbekistan legislative laws do not clarify the supplementary guarantees and are stated in such general terms so that actual application of the law leads to misunderstandings.

It should be noted that the investment law of Uzbekistan indeed establishes the provisions of additional guarantees for particular investments, doing business in the sphere of sustainable development and other fields listed in the law. Under the investment contract foreign investor is able to enjoy the financial assistance in their project, a special tax and customs regime, engineering and communication network provisions and other additional benefits given by state, in governmental decrees. However, in fact there is no legal tool that can protect foreign investor from the further adverse changes in legislation. This deficiency of legal security leads to the two main points: 1) insufficiency of given promises, which seem unreliable due to lack of clarity; 2) weakness of the legal regulation and mechanism to secure the provisions of investment agreements.

\section{NEWMONT v Uzbekistan case}

The NEWMONT v. Uzbekistan case is the good example of the negative outcomes of instable legislation. NEWMONT is one of the joint venture that had investment business in Uzbekistan and harmed the project after the adoption of the new law and suffered from the weak legal protection. This investment project was based on the investment contracts

\footnotetext{
1 "Umirdinov, Alisher. 'The End of Hibernation of Stabilization Clause in Investment Arbitration: Reassessing Its Contribution to Sustainable Development.' Denv. J. Int'l L. \& Pol'y 43 (2015): 455-589.," accessed May 19, 2016, https://litigation-essentials.lexisnexis.com/webcd/app?action=DocumentDisplay \&crawlid $=1 \&$ doctype $=$ cite $\&$ docid $=43+$ Denv.+J.+Int $\% 271+$ L. $+\% 26+$ Pol $\% 27 \mathrm{y}+455 \&$ srctype $=$ smi\&srcid $=3$ B $15 \&$ key $=521266$ ea $413609776 f 0532 \mathrm{a} 371 \mathrm{~d} 922 \mathrm{ec}$.
} 
concluded with state authorities and included the stabilization clause to secure the contract provisions from the further legal changes.

In 1992, "Zarafshon Newmont"1 (Newmont) joint venture was treated with special privileges $^{2}$ for foreign investors by Uzbekistan government. The activity of Newmont was regulated by a special decree of government. According to that decree joint venture for the whole period of its activity has been granted Most Favorite Nation (MFN), including individual tax and customs privileges. ${ }^{3}$ In particular, the joint venture has been exempted from payment of income tax to achieve cumulative gains in the amount of the initial investment of the founders, as well as rose for these purpose loans totaling 300 million US dollars. After reaching a cumulative profit of the total amount of taxes levied on the joint venture should not exceed $10 \%$ of the income of the joint venture.

The dispute between the government and the enterprise started after the adoption of the new law in 2006 abolishing all exemptions previously granted to foreign investments. Thus, the new regulation unified tax regime for companies with foreign assets, without any regard for generally accepted in the international economic relations, and principles of FET and "stabilization clause", which supposed to not proliferate the new regulations for agreements already concluded before. ${ }^{4} \mathrm{On}$ September 29 after the lawsuit Economic Court of Navoi region declared bankrupt Uzbek-American joint venture "Zarafshan-Newmont", $50 \%$ owned by the US Newmont Mining, and identified the three months to liquidate the company. After what this case has been settled in international arbitration. ${ }^{5}$ Overall the outcomes of the proceeding was negative for both parties as foreign investor lost its assets and time, also government decreased its authority as host state. Annulment of benefits provided by the government can be reasoned from the state points of political and economic interest of the country. However, from the point of international law the state indeed did not commit a gross violation. Uzbekistan as a sovereign state has a right to issue new law in a favor of public and state interests. Although the state does not waive the payment of compensation for the breach of the agreements, there is still the issue regarding to the scope of the harm that must be compensated.

1 "Zarafshan-Newmont Joint Venture - 50\% Newmont Owned for Newmont_Mining_Corporation (NEM)," accessed May 19, 2016, http://www.wikinvest.com/stock/Newmont_Mining_Corporation_(NEM)/Zarafshan-newmont_Joint_Venture_Newmont_Owned.

2 Постановление Кабинета Министров Республики Узбекистан “О Мерах по Обеспечению Эффективного Функционирования Узбекско-Америкаиского Совместного Предприятия «Зарафшан-Ньюмонт» и Предоставлении Ему Правительственных Гарантий," за ПКМ №151б Март 27, 1992 г. (Decree of Cabinet Ministrie of the Republic of Uzbekistan "On Measures to Ensure the Effective Functioning of the Uzbek-American Joint Venture "Zarafshan Newmont" and granting that joint venture with government guarantees" ПКМ №151б March 27, 1992. accessed May 19, 2016, http://lex.uz/pages/getpage.aspx?lact_id=405134

3 "Zarafshan-Newmont Joint Venture - 50\% Newmont Owned for Newmont_Mining_Corporation (NEM)."

4 "Zarafshan-Newmont Case and International Investment Arbitration against Uzbekistan: Interpretation of Consent by the Host State and Relevance of National Legislation," The Journal of World Investment \&amp; Trade 9, no. 5 (January 1, 2008): 377-86, doi:10.1163/221190008X00197.

5 "Zarafshan-Newmont Joint Venture - 50\% Newmont Owned for Newmont_Mining_Corporation (NEM)." 
Thus, the application of stabilization clause with uncertain legislation may entail the negative circumstance for both parties of investment contract. From the point of the foreign investor, any adverse legal conditional changes may lead to the deferment or even termination of the investment project that can bring to the failure of business. Meanwhile, from the prospective of Uzbekistan as developing country may face the risk whether to limit its sovereignty power to enact a new law, or to execute the legislation power and pay the compensation for the breach of contract provisions. In both case Uzbekistan has hazard to lose its status as host country.

In sum, among the international commercial contracts such investment contracts concluded between state and private investor has the features that complicates and increases the importance of the contract. The conflicting interest of the contracting parties and their unequal status will always leave the risk for the dispute. In this case, it is important to have a pre-agreed warranty not to breach the contract, and ways to resolve the dispute.

Thus there are three main points that lead to legal instability and weaken Uzbekistan as a host for foreign investment: The first point is the frequent amendments implemented onto the investment legislation which means unreliability of legislation for foreign investors. The second is the ambiguity and vulnerability of promises given in investment law which leaves broad space for interpretation. And the third one is contrasting interest of parties inherently have an unequal status. Considering those arguments and facts stated above it can be determined that the application of stabilization clause in terms of both national legislation and investment contracts still stays weak and need to be amended and clarified in order to reach the further development of investment climate of the state. 


\section{THE SYSTEM OF ADVOCATESHIP AND MANAGEMENT OF CORPORATION: FOREIGN EXPERIENCE}

\section{V. Davlyatov}

\section{Abstract}

In this paper author try to explore the system of advocateship and management of corporation in a case foreign experience.

Keywords: advocateship, management, corporation.

The business affairs of a corporation are managed by a board of directors, not fewer than three, each of whom must be a stockholder. They are elected by the stockholders and their terms, etc., are prescribed in the articles of incorporation. They are the general agents of the corporation; they may issue and sell stock; declare dividends; appoint or elect officers to manage the business of the corporation and act as its agents; make loans; execute mortgages on the corporation's property; buy property needed; and in general perform all such duties as the by-laws and charter given by the State permit. This includes not only those specifically stated but those necessary to carry out the provisions of the by-laws and charter. The directors and officers of a corporation cannot legally engage in ultra vires acts, that is, acts beyond the scope of the corporation's charter powers. If they exceed, or attempt to exceed, these powers, the stockholders or creditors may apply for an injunction to restrain them. This would be so, even if the majority of the stockholders consented to the violation, for a minority may always insist that the limits of the charter powers be observed. If neither of the parties to an ultra vires contract has started to perform his part the courts will not compel him to do so. In most courts it has been held that if either party to an ultra vires contract has done his part the other party will be compelled to perform. If both parties have performed the courts will let the matter remain as they find it. The directors are bound to exercise reasonable care in the conduct of the corporation's affairs, and are liable for negligence, dishonesty, or breach of trust (for they are in a position of trust in their relation to the stockholders).

A corporation is managed by its board of directors, which must approve major business decisions. A director can be, but is not required to be, either a shareholder or an officer. Just as representatives in Congress are elected by voters, directors are elected by the shareholders and typically serve for a limited term. Each corporation must have at least one director.

Examples of procedures which must be approved by the board of directors include:

-Declaring a dividend

-Electing officers and setting the terms of their employment

-Amending bylaws or the articles of incorporation

-Any corporate mergers, reorganizations or other significant corporate transactions

Directors of a corporation owe "duties of loyalty and care" to the corporation. Generally, this means the directors must act in good faith, with reasonable care, and in the best interest of the corporation. If a director stands to personally gain from a transaction with the corporation, he or she must disclose this fact and refrain from voting on the matter, if possible.

${ }^{1}$ Valisher DAVLYATOV, Chief researcher of Legislation and parliamentary research institute under the Oliy Majlis of the Republic of Uzbekistan. 


\section{THE RIGHT TO APPEAL: THE EXPERIENCE OF THE STATES OF THE CIS AND ASIA}

\section{S. Yusupov ${ }^{1}$}

\section{Abstract}

This article examines the issues of increasing citizens 'activism in public life, the creation of mechanisms corresponding to the requirements of the time, progressive and exploratory aspects of the experience of the CIS and Asian states in regulating citizens' appeals for participation in public administration, as well as reforms to improve national legislation in this area.

Keywords: appeal, complaint, official, civil servant, registration number of complaint, document certifying receipt of complaint, e-mail, identification of electronic appeal.

State (Government) - Individual (human) - right (law) defines and maintains not only the goals and mechanisms of democratic progress as an interconnected subject and object, but also their harmony in social change, impetus to development, and ultimately, democratic progress indicator.

None of them can be overlooked, and the harmony between them, dialectical connections, and demanding one another tend to have a vibrant and dynamic society. This development is an ongoing process, and the democratic development, as long as the society does not stop at a fixed, permanent level, develops according to the requirements of the times and enriches with vital and political experiences. There is no complete form of democratic development; it is a reflection of the relationship between the state (Government) - individual (human) - rights (law), which is a part of society. The more democratic, constructive, and targeted these relations are the more democratic, progressive, the more mature.

The national democratic development in Uzbekistan requires further increase of the population activity in the social life and, in this respect, the creation of mechanisms that meet the requirements of the time. At the same time, radical reforms are being carried out in our country to ensure the participation of citizens in public administration, their appeal to the state bodies. In this article, we want to analyze the experience of the CIS and Asian countries in working with applications and their advanced and learning needs.

The procedure for working with the appeals forms a special aspect of public service. This includes the creation, registration, processing of data, collecting and storing documents related to processing applications. The more structured the work with the appeals process, the more correctly structured and properly documented the basis for timely and accurate decision making.

The Law of the Republic of Kazakhstan "On Consideration of Individuals and Legal Entities" has confirmed the forms of appeal in the form of official requests and responses. According to the law, the formal requirement is the person's request for personal or social information, and the answer is to express one's attitude to the domestic and foreign policy conducted by the state, as well as to the events and phenomena of a social character ${ }^{2}$.

The application in Lithuania is approved by the date of receipt of the application, the date of receipt of the application, the name of the official who accepted the complaint, the civil servant or the employee's name, surname, telephone number, a registered document of

\footnotetext{
${ }^{1}$ Sardorbek YUSUPOV, Tashkent State University of Law, 3rd course doctoral student, Uzbekistan.

${ }^{2}$ Law of the Republic of Kazakhstan dated January 12, 2007 No. 221-III "On the procedure for considering appeals of individuals and legal entities".
} 
the complaint. A document confirming the acceptance of the complaint shall be submitted to the person or sent by mail or by e-mail ${ }^{1}$. It is noteworthy that the law requires that the body of the State Authority be obliged to establish at least two additional hours a week after the end of the working day to accept petitions and complaints. This approach, of course, involves the interests of the employer and other employers.

Administrative jurisprudence is smaller than the Roman-German or Anglo-Saxon legal system, which is in the process of forming and, therefore, is of interest from practical point of view. In Japan, due to its mentality, it is preferred not to control by law enforcement agencies (prosecutors, courts), but to the administrative control with "internal" and specific conciliation procedures ${ }^{2}$.

Most authors use only four basic methods of legal protection (four models or four systems of administrative administration) against citizens' illegal actions and decisions of executive authorities and their employees, and, consequently, the legal and institutionalization of such protection - specialized bodies - courts, courts, tribunals, and others. ${ }^{3}$ These methods of ensuring the legal protection of citizens in the field of mass-legal actions are as follows:

- General court Consideration and resolution of complaints against actions (decisions) of courts of general jurisdiction by the courts of general jurisdiction, which is used in Russia as well. Moreover, with the adoption of the commented law, the French (administrative) protection of civil rights in Russia is becoming increasingly important;

Many authorities who object to the administrative way of appealing against the actions (inaction) of an official are convinced of the advantages and disadvantages of this method. L. V. Ivanova points out the following advantages: the existence of various forms of complaint and the methods of their submission; openness and simplicity of procedures; consideration of complaints by experts in a particular area; response speed.

From the shortcomings in the administrative complaint, it can be seen that: the procedures, procedures, and poor regulation by the law enforcement officials, the availability of institutional interest, and the complexity of execution of decisions 4 .

In a number of CIS countries (e.g., Russia, Tajikistan, etc.), the law permits a senior official or court to choose a consecutive (first administrative, and then a court) case.

In the latter case it is necessary to observe the period of consideration of a written application. An administrative complaint will be as appealing. Therefore, a complaint may be filed only after the expiration of the period of time for the official to consider the appeal (30 days). In Tajikistan, the type of appeal to the Constitutional Court is differentiated as a "petition."5

\footnotetext{
${ }^{1}$ See: Law of the Republic of Lithuania of June 27, 2006 No. X-736 “On Public Administration”. ${ }^{2}$ See: Butorin A. E. Administrative Justice in Russia (historical and legal research): Author's abstract. dis. ... Cand. legal sciences. - Vladimir, 2006. - p. 22.

${ }^{3}$ See: for example, N.Yu Hamaneva. Right of citizens' complaints in European socialist countries. Kazan, 1984. - p. 23; Vedernikova O. N. Administrative justice (the experience of foreign countries) // Judicial reform: results, priorities, prospects: Conference materials. Series "Scientific reports." - M .: MONF, 1997. - № 47. - pp. 52-60; Demin A. A. The administrative process in developing countries. p. 9; Chechot D.M. Administrative Justice. - p. 36-37.

${ }^{4}$ See: Ivanova L.V. Administrative Appeal against Violations of the Rights and Freedoms of Citizens, Legal Entities, and Individual Entrepreneurs: author. dis.... Ph.D. - Omsk, 2005. - p. 16.

${ }^{5}$ Saidov I. Kh. Constitutional right of citizens to appeal and its implementation in the Republic of Tajikistan: Dis.... Cand. legal sciences. - pp.71-73.
} 
In abroad, the issue of approving the applicant's identity, including electronic identification, will be resolved differently. In most countries, there are no requirements for authentication by electronic digital signatures (EDS) when individuals apply. For example, in accordance with article 7, paragraph 3, of the Russian Federation Federal Law "On the Procedures for Consideration of Applications of the Russian Federation" in 2006, "electronic government applications filed with a public authority, local self-governing body or officials, in the manner prescribed by this Federal Law will be considered.

In the application, the citizen should indicate his / her last name, first name, patronymic (if any), e-mail address, if the reply should be sent in the form of an electronic document, if the reply should be sent in writing. The citizen shall have the right to attach the required documents and materials to this application electronically, or send the specified documents and materials or their copies in writing ".

In accordance with the law, an application for electronic mail will be sent to the e-mail address indicated in the application, either in the form of an electronic document or in the written form, with the postal address indicated in the application. In the application, the application will not be answered in the absence of the citizen's surname or the postal address to which the response should be sent ${ }^{1}$.

The Law of the Republic of Belarus "On Appeal of Citizens and Legal Entities" (Article 25) in 2011 establishes specific requirements for electronic applications: "General computer network Requirements to special sections of the Internet for the placement of e-mails on official websites of state bodies and other public organizations Belarus By the Council of Ministers of the Republic ". The Law of the Republic of Kazakhstan "On Procedures for Consideration of Individuals and Legal Entities" does not contain requirements for authentication via EDS, but Article 6 requires the signature of the application. The provisions of Article 6 of the Kazakhstani Law are of particular interest, and it is expedient to use it in national law: "The date and time of the applicant submitting a written application directly to the subject, and the spam given to the person who has received the request."

The Law of the Republic of Kyrgyzstan "On the Procedure for Considering Citizens' Appeals" of February 26, 2008 No. 16 (July 15, 2009, No. 214) calls for appeals, suggestions and complaints, as well as individual references, i.e. a citizen's appeal and collective appeal - citizens' appeals on behalf of citizens, and resolutions (decisions) of rallies and assemblies. Appeals of legal entities are not regulated by law.

At the same time, the recourse definition should be noted - "new evidence or newly revealed facts are not subject to review (verbal or written) if there are completed audit materials and the citizens have been responded in the manner prescribed by this Law. New evidence or reversed cases shall be considered in the manner prescribed by this Law "(Article 10$)^{2}$.

The Lithuanian legislation establishes the principles of public administration under the provisions of the Constitution of the Lithuanian Republic, guarantees the right of a person to appeal against actions, inaction or administrative decisions of the subjects of the people's administration, as well as legitimate and impartial consideration of petition, complaint and communication ${ }^{3}$.

\footnotetext{
${ }^{1}$ See: Statements of the Parliament of the Republic of Kazakhstan, 2007, N 2, Art. 17; "Kazakhstanskaya Pravda" dated January 30, 2007 N (25,261).

2 See: Newspaper "Erkintoo". - 2007, may, 22. Issue-37

${ }^{3}$ See: Law of the Republic of Lithuania of June 27, 2006 No. X-736 “On Public Administration”
} 
The Estonian experience, which is one of the countries in the former Soviet Union, is of particular interest. There is a high level of reference system based on information and communication technologies (ICT). While Estonia has the lowest level of country's informatization, it has started introducing ICTs, and today $90 \%$ of the country's population uses computer networks to solve daily problems and almost $99 \%$ of all public services are open online.

For example, making payments for social security, participating in elections, registering institutions, submitting tax returns, obtaining a driver's license, registering the birth of a child, placing cars at a parking lot through a single public services portal, you can control your schooling and spend a lot of time and money doing other useful things. At present, Estonia has three ways of identifying the Internet: ID card, Digi-ID card and Mobile ID identification.

The most common means of identifying citizens with more than $90 \%$ of the Estonian population is ID card, which performs two main functions of replacing a traditional passport: First, it is a simple tool for identifying a real person, and secondly, a chip with two attachments (PIN- coded identifier and e-digital signature application with its own PIN) ${ }^{1 .}$

In conclusion, it can be noted that foreign practice shows that the laws and practice of consideration of applications of individuals and legal entities are the means to ensure their rights and interests, as a necessary and effective way of protecting and exercising various rights of individuals and organizations. Some examples and practices of legal decisions of foreign countries can be fully utilized in the process of working with the complaints of state bodies in Uzbekistan in the field of physical and juridical persons as well as in the improvement of the relevant legislation.

${ }^{1}$ See: the website of the Center for the Study of Legal Problems - www.cipp.uz. Date of circulation: $07 / 25 / 2016$ 


\title{
ECONOMICS
}

\section{ACTUAL FACTORS OF DEVELOPING PUBLIC FINANCE SYSTEM}

\author{
1M. Mansurov
}

\section{Abstract}

In this article, on the basis of the reform of public finances, to settle the expediency of improvement of the state budget and its future development.

Keywords: liberalization, national revenue, budget, financial policy, Finance, Uzbek model of economic development.

After our country gained independence, clear programs have been elaborated in all aspects of development of the society, first of all in further deepening the reforms and deregulation of the economy, in transition of development to market relations, therefore, for instance, broad reforms have been carried out in the finance system as well.

With adoption of the constitution of the Republic of Uzbekistan, the legal framework have been established for the financial policy of our country, the trend has been set up for developing the financial system. Due to the consistent and fair policy implemented in the financial, budgeting and monetary fields, perfect monetary system was created in our country.

In his work "The esearch into the nature and reasons of people's welfare", economic scientist A.Smith, United kingdom, has analyzed the public finance issues and proven the possibility of using the state finance in equitable distribution of the country's national income, created the theoretical fundamentals of public budget and tax policy. For instance, the scientist proposed that while first peace is required to take the public welfare from the low stage to the upper stage, second, public finance (public budget, taxes, public debts, expenses, etc) should be skillfully managed, all the rest will take its due course thanks to natural efforts. A.Smith's this teaching has had its positive effect on many country's economies for years.

Along with being the main sphere of the country's financial system, the state finance provides also the state with financial resources in performing economic, social, political and environmental functions. It helps regulate effectively such matters as meeting the needs of development of production, R\&D, supporting the state and society security. In this way, the state provides low income and needy groups with social protection, takes steps to faster develop the priority aspects of the economy.

Meanwhile this proves the effectiveness and correctness of the Uzbek economic development model, particularly under the economic/financial crisis, which is based on five principles worked out by our President ${ }^{2}$.

For instance, in 2013 alone, the country's GDP grew 8 percent. The inflation rate made at 6.8 percent, lower than the projected level, the external national debt made at $17 \%$ against the GNP. In 2013 , despite the tax burden in economy was brought down from $21.5 \%$ to $20.5 \%$, individual

1M. MANSUROV, Tashkent Textile and Light Industry Institute, Uzbekistan.

${ }^{2}$ The topic problems of reforming the state finance. IQTISOD VA MOLIYA,T:2010. 
income tax lowest rate from 9 to $8 \%$, the public budget was implemented o.3 percent surplus against the GNP1 .

It is known that any state's financial activities include, first of all, setting the budget, securing its implementation, implementation of tax policy, effective operation of bank/credit systems, achieving stability of monetary relations.

In such a case, enactment of the Laws of the Republic of Uzbekistan re The Tax Code, the Budget System, the budget execution through the Treasury, the Central Bank, the Taxes, the Insurance, Regulation of Foreign Curency, the Securities and Stock Exchanges, Foreign Investments and protection of Foreign Investors' Rights, Employment of Population, Public Budget Implementation Through Treasury and other laws is essential in regulation of financial relations, building up the financial system and effective performance.

And therefore, the economic essence of the state finance, in the process of distribution and re-distribution of a part of the value of the gross social product and national wealth, consists in the relations in financing the society's growing social/cultural events along with creation of centralized and decentralized financial resources that are at the state's and state enterprises' disposal as well as along with expanded production.

The state finance's economic structure, in a true sense, is not the same everywhere, though it consists of inter-related links, it is the combination of links that differ from each other in the functions they perform.

The state finance system is a single complex of component and functional bodies that provide financial transactions, they save cash funds and carry out spendings using transactions. $^{2}$

The state finance is the means of re-distribution of a major part of the GDP of developed countries: in Japan: $1 / 3$, France, Netherlands, Norway: $1 / 2$, Sweden: $2 / 3$, Russia: $1 / 3^{3}$, While in Uzbekistan in the last years, through public budget: $35-40^{4}$ percent, and about $1 / 3$ of the national income is distributed.

The state finance links include public budget, state earmarked funds, state credit and finances of state-owned enterprises. Today, many publications highlight the significance of state finance, state credit and finances of enterprises (Diagram 1).

${ }^{1}$ The speech of Islam Karimov, the President of the Republic of Uzbekistan at the meeting of the Cabinet of Ministers dedicated to the results of socio-economic development of our country in 2013 and the most important priority aspects of the economic program for 2014.

${ }^{2}$ T.Eshnazarov, The fundamentals of the treasury system in the Republic of Uzbekistan, IQTISOD VA MOLIYA" editorial office. T: 2012.

${ }^{3}$ The priorities of state regulation of economy. Rostov-on-Don: СКАГС, 1998. P.34.

${ }^{4}$ S.V.Chepel et al. Macro-Economy - M:. 2007. P.22-39. 


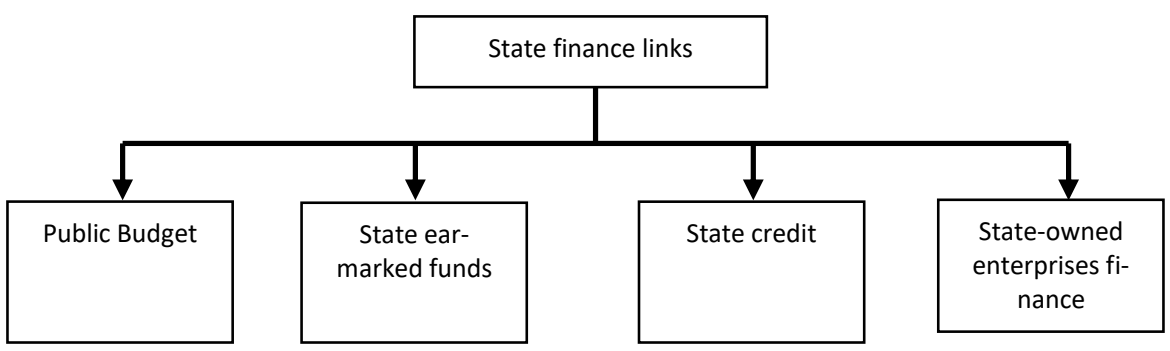

Fig. 1. Structural components of state finance

Separation of state finance into individual links is based on difference of functions of each link as well as on difference in the methods of creation and use of centralized and decentralized funds. The general state centralized funds are created by way of distribution and re-distribution of national income generated in production. The important role that the state has played in economic and social development will result in the need of centralization of a major part of financial resources it has at its disposal. The forms of their use is demonstrated through public budget and state earmarked funds. The need to address the state economic, political and social goals are met at their cost. The forms and methods of creation and use of funds are used through the credit and insurance links of the financial system. Beside this, it is feasible to add to the state financial system insurance funds and stock market in which the state has its interests. Also, the finance of state-owned enterprises also play a leading part in securing certain tempos of development of all sectors of the national economy, in redistribution of financial resources between the sectors of the economy and the country's territories, between production and non-production spheres and between property forms, between certain groups and levels of population.

In such a case, the Public Budget is considered to be the main link of the state finance, being the form of securing the state management body functions, and the country's main financial plan. The state finances through the Public Budget development of the national economy, social/cultural events, defense, state government and management bodies.

In our republic, the Public Budget structure consists of two links, the Republican Budget and summary of local budgets. Events of social significance are financed from the Republican Budget. The local budgets mainly finance events of local significance. For instance, while organizing territorial infrastructure, labor resources are recovered, social events are held that serve to improve the public welfare.

Financial relations between the state and public come into existence, first of all, due to receipt of various payments and preferences from the Public Budget. Certainly, relations of such types will keep changing at different stages depending on clear situations, management methods and objectives and goals of running a business.

Due to transition of the economy to market relations, there will arise a need to cover the Public Budget revenues with taxes and payments that do not come under taxes, the mutual relations of the state with enterprises, organizations, the public in creation of the Public Budget are regulated under economic laws.

Therefore, in our opinion, in reforming the state finance it is preferable to improve the Public Budget first and to elaborate its prospective concept. The Public Budget prospective concept dictates creation of transparent medium-term and long-term Public Budget aimed at results and programs, formulation of improved State Procurement Law that sets up the procedure for purchase of goods and services for state, regional 
administrations and Public Budget organizations in terms of spending state and Public Budget funds, introduction of modern IT in the state financial system, further development of the country's treasury system, orderly and efficient means of managing the state assets and liabilities and obligations, viz.: audit of state finance and to fully introduce in practice The Public Budget Code that brings the existing materials in the form of Public Budget statutory acts and guidelines into a single system.

In this case, while the duty of the audit is to assist the state finance in complying with the requirements of the statutory acts; to check reliability, accuracy and fullness of documents and to prevent mistakes; to meet the objectives that specify implementation of orders and directives; identification of extortions; prompt preparation of data, passing the State Procurement Law will serve to improve the effectiveness from use of the public funds, to enhance trust and to create great potentials for transfer of Public Budget authorities $^{1}$. While the Public Budget Code will facilitate clear planning the Public Budget and Off-Budgetary Funds and appointment of persons responsible for its execution will make the Public Budget and its execution further transparent.

Beside this, more effective use of public funds will be achieved by turning the treasury system into the full user of public revenues and expenditures and by enhancing its responsibility as independent legal entity and their efficient management. Also, by way of actual introduction into practice of financial activities of business entities in which public interest is over 25 percent through the treasury system, it will be possible to systematically use the public funds. Beside this, in the state finance system, by way of using the Internet, the new software that enables to exchange data in real time - to shorten sensibly the total time required for introduction of on-line data exchange system, to provide circulation of legally significant, protected documents and to receive and transmit documents and information. Also, it will lay down the foundation for creating the common information site for the state finance ${ }^{2}$.

In our opinion, if the above-mentioned proposals are introduced, strong sustainability of the state financial policy will be achieved as well as sharp changes will be prevented in the state social and economic development programs, also, a positive impact will be produced on the country's sustainable economic growth.

\section{References}

[1] The topic problems of reforming the state finance. IQTISOD VA MOLIYA,T:2010.

[2] The speech of Islam Karimov, the President of the Republic of Uzbekistan at the meeting of the Cabinet of Ministers dedicated to the results of socio-economic development of our country in 2013 and the most important priority aspects of the economic program for 2014 .

[3] T.Eshnazarov, The fundamentals of the treasury system in the Republic of Uzbekistan, IQTISOD VA MOLIYA" editorial office. T: 2012.

[4] The priorities of state regulation of economy. Rostov-on-Don: СКАГС, 1998. P.34.

[5] S.V.Chepel et al. Macro-Economy - M:. 2007. P.22-39.

[6] T.Eshnazarov, The fundamentals of the treasury system in the Republic of Uzbekistan, IQTISOD VA MOLIYA" editorial office. T: 2012.

[7] The institutional reforms in the state financial system and its development factors, Journal Iqtisod va Moliya -2012 №12

${ }^{1}$ The institutional reforms in the state financial system and its development factors, Journal Iqtisod va Moliya -2012 №12

2T.Eshnazarov.Public Budget and prospects for developing automated data system of its treasury execution. Journal Iqtisod va Moliya -2012 №10. 


\section{INNOVATIVE DEVELOPMENT COTTON PROCESSES IN TWO PRODUCTS}

${ }^{1} \mathrm{~A}$. Khasanov

\section{Abstract}

Thesis analyzes the dependence of innovation and sustainable development of livestock farms on infrastructure development that serves it.

Keywords: livestock, innovation, infrastructure, ecological efficiency.

Innovative development of any sector, first of all, is directly connected with intensification of production, ensures efficient and full utilization of available resources and increase of labor productivity as a result of the use of advanced techniques, technologies and production, as well as new forms of labor organization.

Innovative activity in the livestock sector is related to the production of new or improved livestock products (by quality, appearance and efficiency). These activities are the result of scientific research and development or the modernization of production and the use of advanced marketing techniques.

The cost-effectiveness of innovation activities is determined by the achievement of additional profit by improving the quality of resources and is based on indicators such as cost reduction, profitability, and productivity.

The social efficiency of innovative activities reflects the standard of living of the population and is characterized by the increase in the level of wage earners employed in the livestock sector, by the ratio of real incomes and living wage [1].

The environmental efficiency of innovation activities in the livestock sector is determined by the improvement of the environment and is used to estimate the increase in the volume of environmentally friendly products generated by the sum of UZS total costs.

Our research suggests that, in line with the sustainable and innovative development of the livestock sector in the Republic of Uzbekistan, the increase in the production of livestock products, first of all, the per capita consumption of milk, meat and eggs is brought to the requirements of medical norms and raw materials for processing industry enterprises it is necessary to keep it. However, innovation and sustainable development of livestock farms can be assessed not only by the increase in the number of livestock, but also with the level of development of the infrastructure serving the livestock sector, and not with increased productivity, efficiency or profitability.

When the innovation infrastructure development of the livestock sector is carried out simultaneously with the process of innovative product development, the outcome can be achieved.

The development and maintenance of effective functioning of the infrastructure of the livestock sector should not only be solved by the problems of business entities, but also under state protection. Because network infrastructure, such as the agricultural sector, is in constant need of government support and protectionism policies.

The impact of the development of agricultural production on the natural and climatic conditions in the regions, the soil fertility, the availability of agroresource resources and other similar factors will also have an impact on the development of infrastructure and services in infrastructure. Such effects are directly or indirectly seen [2].

The above-stated attributes of the development of the infrastructure for servicing the livestock sector require a number of factors. Among such factors are the creation and

\footnotetext{
${ }^{1}$ Abray KHASANOV, base doctorate at Termez State University, Uzbekistan.
} 
development of infrastructure entities, taking into account the natural and economic conditions of the regions, the specialization directions of the agricultural sector, the livestock sector placement, the population growth rates and the employment rate. Therefore, taking into account the features of the location and functioning of the region and the livestock sector, it is necessary to take into consideration the following factors in the establishment and development of infrastructure, which serve the livestock sector:

Sale of livestock products and demand for livestock products have regional characteristics. Also, the national composition and traditions of the local population also have a great impact on the consumption of food. Therefore, it is necessary to take into account the availability of markets for cattle breeding and the volume of markets. In other words, the development of commercial and commercial services mainly in dairy and meat cattle breeding will create favorable conditions for the effective functioning of infrastructure facilities, as well as the development of the product industry.;

Changes in the trends in livestock sector specialization and the number of livestock and the growth in crop production should be taken into account. Because of the diversity of animal husbandry specialties and the structure of the products, different services are needed;

The high risk of recessionary risks of farmer involvement in production should be taken into account because of the lack of marketability of the product sales system and the livestock breeding characteristics. This should be taken into account in the development of infrastructure entities, both by the manufacturer and by the service provider.

These infrastructure facilities play an important role in the sustainable development of the livestock sector in the Republic of Uzbekistan.

However, there are problems in the livestock sector that need to be addressed:

Low share of total area for forage crops and disproportionate distribution of livestock by number of livestock;

$>$ Efficient use of feed crops and low productivity of crops;

$>$ Lack of fodder harvesting techniques, most of them are physically and morally obsolete;

$>$ Low level of mechanization in livestock sector.

$>$ Full-fledged zoo-veterinary service. The main reason for this is the lack of qualified personnel in the zoo-veterinary and non-compliance of the level of equipment of zooveterinary stations.

\section{References:}

[1] Q.Abdurahmanov. Labor Economics. Human Development. T .: Science and Technology, 2013, $177 \mathrm{P}$.

[2] Alexander Zabutyy, Ph.D. Animal Science; - Israel Agriculture; - Hannover 2012. - 25 стр. 


\title{
PHILOLOGY
}

\section{THE INSTRUMENTAL SYNTAXEME IN THE STRUCTURE OF THE ENGLISH SENTENCE}

\author{
${ }^{1}$ R. Khabipova
}

\section{Abstract}

The article deals with the identification of differential syntactic-semantic features of syntactic units which express instrumentality in the structure of a sentence and their compatibility on the basis of certain syntactic links and the identification of basic convergences and discrepancies of instrumental syntaxemes in the structure of English sentences.

Key words: instrumentality, syntaxeme, substantiality, connotative, optional, nuclear, predicating, distribution, transformation, locative, ablative, translative, possessive.

The aim of the study is to determine the syntactic positions of the elements expressing instrumental syntaxemes on the basis of categorical attributes of substantiality, procedure and qualification.

On the basis of these differential syntactic and semantic features, instrumental syntaxemes such as proper instrumental, instrumental qualitative, instrumental locative, instrumental causal, instrumental objective, instrumental syntaxeme of the mode of action, instrumental agentive, instrumental translational, locative and ablative syntaxemes were defined.

In determining non-categorical features, we paid attention to the productivity and unproductiveness of expression of these syntaxemes and also determined their variants. Based on the factual materials collected from the works of English authors, as well as from newspapers and magazines, we identified two variants, connotative and facultative.

In connotative version, as G.S. Petrov noted "... one syntaxem can be expressed in several ways in the sentence structure, but they cannot be replaced with each other" $[8,12]$ and "the optional variant of any syntaxem is freely replaced with each other" [11,21].

In determining the actual instrumental syntaxemes in the English language, we distinguish the lexico-semantic groups of components in the position of the nuclear predicating component [NP2], and take into account the lexical meanings of the syntactic units in the position of the non-nuclear dependent component in the sentence structure. Proceeding from this principle, it is possible to divide four groups of lexical units in the position of the nuclear predicating component [NP2-predicate].

Verbs expressing physical actions: to touch, to scratch, to take, to seize, to strike, to wipe, to fight, to throw, to spear, to cut, to injure, to shake, to kill and others.

1. Catherine touched me with her foot under the table. (EH, 218)

2. You are trying to kill two birds with one stone (JG, 103)

3. He cut the cards with his pocket-knife (TH, 384)

4. I killed him with a hatchet (betchet). (DH, 262).

${ }^{1}$ Rivanna KHABIPOVA, Karakalpak State University named after Berdakh, Nukus, Uzbekistan 
2) Verbs expressing a physical action of laying an object in a certain place: to point, to wave, to push, to raise, to place, to move, to pull, to lean and others:

1. Lord Henry pulled the daisy to bits with his long nervous fingers. (OW.25)

2. He had pointed with his finger to the door (JBP, 153)

3) Verbs expressing the effect of purposefulness or the performance of some work: to do, to work, to rub, to detect, to fix, to tie, to open, to steer, to rule, to dig and others:

1. Forsytes opened it with the key (JG, 234)

2. He rubbed his forehead with the back of a huge hand (PA, 221)

3. Working it with his finger, he glanced at Beneden (JBP, 216).

4) The process of observing a subject expressing an action or condition: to see, to look, to watch, to read, to listen, to sniff, to calm, to soothe, to relieve, to cry, to amuse, to dope, to befuddle, and others:

1. Lord Henry looked at duchess with his plumbeous (s (p)lumberous) eyes $(0 \mathrm{~W}, 242)$

2. The lad cried clutching the arms of his chair with trembling hands $(0 \mathrm{~W}, 142)$

3. Linda gazed at me with puzzled eyes (GD,102)

In the English language, prepositions play a major role in the expression of substantial instrumental syntaxemes.

For example:

1.He touched the stars with his thumb and forefinger $(\mathrm{EH}, 122)$

2.Ned Becumont wiped the palms of his hands with a handkerchief (DH.67)

3.Miss Alice grabbed Mimi by the arm (DH.255)

4.He went across the green by the light of the moon (TH.258)

5.Lord Henry purred through his glasses mouse $(0 \mathrm{~W}, 108)$

6.He was breathing through his mouth $(\mathrm{DH}, 16)$

In these sentences, the syntactic units: with ... thumb (1), with handkerchief (2), by the arm (3), by the light (4), through his glasses (5), through his mouth (6) express substantial proper instrumental syntaxemes. One can prove the syntaxemes using the transformation by adding the following syntactic units: with the help of, by means of, with the aid of:

He touched the stars with his thumb and forefingers $\rightarrow$ He touched the stars with the help of his thumb and forefingers.

Ned Becumont wiped the palms of his hands with a handkerchief $\rightarrow$ Ned Becumont wiped the palms of his hands by means of the handkerchief.

3. Miss Alice grabbed Mimi by the arm $\rightarrow$ Miss Alice grabbed Mimi by means of the arm.

4. He went across the green by the light of the moon $\rightarrow$ He went across the green with the help of the light of the moon.

It should be noted that combinations with $+S$, by $+S$, through $+S$ do not always express substantial instrumental syntaxemes. In this respect, L.K. Gainutdinova notes that "the combination with $+\mathrm{S}$, in the sphere of categorical differential syntactic and semantic features of substantiality, can express societality (compatibility) out of non-categorical features - Mrs Hemming went there with Edna Brent (Christie)." [2,10]

Indeed, this sentence is not transformable by the elements: with the help of or by means of. Mrs Hemming went there with Edna Brent $\rightarrow$ Mrs Hemming went there with the help of Edna Brent. In this respect it is necessary to maintain the views of K.E. Smirnova. She 
writes "... when the collocation with $+\mathrm{S}$ expresses a substantial social syntaxeme, one can prove this by transforming it adding the collocation together with "Mrs Hemming went there with Edna Brent."

Mrs Hemming went together with Edna Brent.

It should be noted that when the substantial instrumental syntaxeme is expressed by the models with $+S$, by $+S$, through $+S$, they do not lend themselves to transformation by adding the collocation together with:

He touched the stars with his thumb. He touched the stars together with his thumb. As a result of the analysis of the above examples, we can say that when the substantial instrumental syntaxeme is expressed through models with $+S$, by $+S$, through $+S$, they can be considered optional versions because they freely replace each other.

For example: He touched the stars with his thumbs $\rightarrow$ He touched the stars by his thumbs $\rightarrow$ He touched the stars through his thumbs.

It should be taken into account that in the sphere of the substantial instrumental syntaxeme, it is possible to identify a number of non-categorical differential syntacticsemantic features:

Somebody had seen him through the window. (TH,67)

They went down through the door. $(\mathrm{DH}, 69)$

From doors and window people watched and greeted him. (PA,157)

I stuck my arm out of the window. (GD,7)

Monseur Profond came from the window. (ZG,123)

In the examples, through the window, through the door, from doors and window, out of the window, through the woods, the collocations express not only the substantial instrumental syntaxeme, but in addition to them they cover there is a substantial instrumental locative, locative - ablative, locative - translational syntaxemes. 


\section{CONDITIONAL AND UNCONDITIONAL SIGN}

1M. Rakhimova

\section{Abstract}

This article focuses on specific and distinctive features of unconditional and conditional signs that are the types of signs.

Key words: character/sign, unconditional, conditional, referent, word, perception, motivation, identifier, identified part, image.

The term "sign" in scientific literature has far broader meaning2 2 In particular, "the concept of sign" is used for not only pure conditional signs but also unconditional signs that is, the "unconditional signs" that can naturally report their subject matter. According to V. M. Solntsev, "sign" characters are actually the symptoms, features of these subjects. These types of things (features, symptoms) do not have unnatural, unconditional, conventional link with the objects they represent. Nevertheless, these objects (natural features, symptoms) can also show the objects that are related to them (e.g. smoke its flame) under certain circumstances. Therefore, it is better to use the expression "character setters" rather than "pure sign" of the subject (natural features, images with different level of accuracy, such as image, photographs). These character setters can never become a pure sign. The distinctive feature of unconditional characters is that they are perceived by the subject matter (fire through the smoke) on the basis of the object being observed. In these cases, unconditional sign situation like the case of a pure sign appears. However, in such cases we cannot say that the result (smoke) is a sign of the cause (fire). Thus, it can be a sign (unconditional character, smoke) only when the cause (fire) is invisible. It is a situational or relative sign. Symptoms (such as the case of the external symptoms of the diseases) are such kinds of characters. Pure or conditional characters do not have natural, cause-bound links with the subject they represent. We cannot have an idea of the subject that is reporting through the material (subject matter) of the pure sign. The unconditional smoke character we mentioned above can give information about the fire it represents. For example, the weak, sparse smoke can indicate weakness of combustion while dense, hoarse and black smoke can show the combustion of the solid which is hard to burn and etc. The conditional character such as the sound of the word informs another thing rather than itself and does not indicate any particular feature. People assumed to call certain sounds or set of sounds as a sign in a compulsory or optional way.

For example: the Uzbeks used the term " $\mathrm{H}+\mathrm{O}+\mathrm{H}$ " (bread) for one type of food while the Russians received a set of sounds that is " $\mathrm{x}+\pi+\mathrm{e}+\sigma$ " for the same term. Furthermore, we cannot have any idea about a person by his/her name ${ }^{3}$. The name, which is a conditional character, recalls the image of the subject in which it is characterized. It also performs a learning function.

${ }^{1}$ Maftuna RAKHIMOVA, Teacher, Kokand State Pedagogical Institute, Uzbekistan

2V.M.Solsev. Language is as system-structure education. M.: 1971. стр 112

${ }^{3}$ M. Rakhimova. Leksikal nomeme. Actual problems of uzbek linguistics. Tashkent.. 2011. p.160 
V.M.Solntsev reminds that the mark must have the materiality that can be perceived to mean and express something 1 . Also, this material (subject) should be appropriate in order to be a sign. Any material (subject) can be a sign only when it is combined or it is given the opportunity to show another subject by people. When people attach something to the material (subject) so that it could perform a sign usually called meaning. For example: the meaning of the sign, " $\mathrm{s}+\mathrm{m}+\mathrm{o}+\mathrm{k}+\mathrm{e}$ " is fire and the sign, $\mathrm{f}+\mathrm{l}+\mathrm{o}+\mathrm{w}+\mathrm{e}+\mathrm{r}$ means the plant that gives aesthetic pleasure to people.

A.Nurmonov describes a sign from the point of view of psychology as follow: "The sign is a thing that can be perceived, and a means to inform the preceptor about itself as well as what is beyond that. Two features of the character recognition: a) being perceived, it is necessary to have material basis for perception. There are different material basis: sound (acoustic), taste (gustatory); b) to give information about itself and other things. Nurmanov reminds that two objects that are replaced by each other would not be a sign². It can become a sign only when one is constantly exchanging with the other and it is reflected in a human mind. For example: only when the attitude of the smoke - fire is reflected in the human mind, it convenes, conditional signs produce subjective. It provides information about conditional production. The sign depicts, describes, and encodes something (expressed, referent) in the human mind. The sign does not only, express its referent but also it describes the referent, provides the characterization as well as it serves as its permanent representative in place of the referent it represents. The sign is the form of imagination about objective or semiotic referents in a society or individual ${ }^{3}$. It is common to have abstract levels for signs. Natural characters are closer to their referents; others are distant while some are characterized by the meaning or concept or significant in a natural contact. The object that is expressed through a sign is denotate or referent.

\footnotetext{
1 V.M.Solsev. Language is as system-structure education. M.: 1971. p. 112

2 Nurmanov A. The theory of lingvuistic sign. Tashkent. 2008. p.13-22

3 Solomonnik A. Dictionary of semiotic terms. Minsk.2009
} 


\section{BIOGRAPHIC METHOD IN “RUZI CHORIYEV'S LAST WILL”}

${ }^{1} \mathrm{Kh}$. Khudaymurodova

\section{Abstract}

The author has just dreamed of the biography of the artist. Author's painting has been so sharpened that he had been shot dead by the deceased, his memories, and his comments. The events that led to the death of one another. Painting is a fun, distracting idea, or skepticism, stupidity, cruelty his comments

Keywords: painting, biographical method, living environment, cruelty, artist, ethical, mental-psychological condition, comments

What is Biographical Methodology? This is a very important question as to how to deal with the biochemistry: "Biographical method is an essential and effective tool for infertility. Exercise is crucial to personal life, living environment, mental-psychological condition, personality, self-esteem, curiosity of laboratories, and lifestyles in history.

The biographical method of the art can be used as a part of the novel, story, historical or otherwise. Autobiographical works are also used to the same method. For example, A.Kahhor's "O'tmishdan ertaklar", Oybek's "Bolalaik" and others.

Biochemistry is considered as accurate, authentic, and ethical. Unifying is a human body and an organism. In nature, the biological product is considered to be the most famous hero of the world. If the work of the artist, the cartoonist, the author, was critically ill. Writing as a hero of every important detail. For example, a hero's work letter, memory, dashboard, pods and jumps.

The biographical work of the author, the first, the sophistication, the information needed to create the information, the need for clarity. Irving Stouning's bio-fictional idea, but it fits to all biographical ideas: "Biographical citation author of one person or group of people has the right to use the bibliography. It's a complicated process of classification of material, which means that millions of people who want to live in the mood of life will not be able to live in the same way as everyday, "he said.2

On the Uzbek literature, biotechnology is based on the biological methods of Nodir Normatov's"Ròzi Choriyevning sòngi vasiyati" with a unique Roman novel. N. Normatov did not justify the artists, but the artists and the art of painting, as well as the researches. The caravan, the author of the artist, Ruzi Choriyev, spoke to the audience on the sidelines. N. Normatov's book is a collection of memorable memories, painting of the latest painting, as well as collapsed. Ruzi Choriev has been instrumental in working toward the N. Normatov's legacy. As a result of the tens of thousands of people, he had been beaten by the bombing, and the other two were executed by the Red Crescent, Shepherd, in the village of Pohhurt. This is just a frustrating and frustrating game.

The Chiangev Chiang's book has life and politics. The reason for the exclusion of the drug nickname N. Normatov is that: "... Kunninging rushes on the rocks with the same locust:

${ }^{1}$ Khurriyat KHUDAYMURODOVA, researcher, TerDU, Uzbekistan.

2 Стоун И. Биографик қисса хақида (Оксфорд университетида ўқилган маъруза) / Жахон адиблари адабиёт хақида (Озод Шарафиддинов таржималари). - Т.: Маънавият, 2010. - Б. 100. 
- In the form of coatings, as well as wool, woven fabrics, painting. They have come to realize their talent, but also. This is not an artificial lady, but it's a strange thing to say. The book is a collection of books, so that the book is asking questions ...

I have been talking about the turmoil, the art of art, the life of my thoughts. Prior to the day of the hearing, Cain, I would like to have a copy of the award, as well as the effect of the artist. In essence, artist artists also created a point of view. It's a good idea, but it's a good idea, and it's a good idea.

The author has just dreamed of the biography of the artist. Author's painting has been so sharpened that he had been shot dead by the deceased, his memories, and his comments. The events that led to the death of one another. Painting is a fun, distracting idea, or skepticism, stupidity, cruelty. his comments.However, it is a stroke or a stroke. The artist's paintings are historic, and the bookstores are incredible. These are the memoirs and memorable conversations. Important, "Chaievnings Day Essays" bookstore. Roman-Esse Cherryev's freight portfolio is visible. ${ }^{1}$

Roman-Esse consists of parts. The first part is the named "Kamalak yashaydigan uy". It is described by the artists, the artists, the first art of the arts, the memorial of the memorial, the descent. "Rassomning so'ngi kunlari" is a part of Ro'zi Choriev's life and art right in the right direction, thoughts, and impressions of trips.

The bookstore is "Rassomning so'ngi vasiyati", featuring the story of the death of the Choriev's, a reminder of the past and presentations.

The book is below. Bookstore has been able to produce realistic artists, artists, and literally. Generally speaking, the famous "Rassomning so'ngi vasiyati" is illustrated by the famous painting of life.

${ }^{1}$ Норматов Н. Таассуротнинг рангин эшиги / Рўзи Чориевнинг сўнгги васияти. Т.: Санъат, 2008. - Б.4. 


\title{
ADVERB OF TIME IN ENGLISH AND RUSSIAN LANGUAGES
}

\author{
1M. Abduvohidova
}

\section{Abstract}

In special studies on linguistic units with temporal meanings, the description is usually based on a formal sign - the use of the noun of that or another group and the meaning is indicated as the description of each individual unit proceeds.

Key words: adverb of time, foreign researches, part of speech, morphological feature, adverbial category.

Следует отметить, что в отношении русского языка обстоятельственное изучение наречия описано академиком В.В.Виноградовым и многими исследователями, та в английском языке такое исследование в полном объеме ещё не проделано. Поэтому в большинстве исследованиях по грамматике наречие трактуется настолько расплывчато, что в сущности теряет всякие определенные очертания. Вопросу об отграничении категории наречия от смежных категорий и другим вопросом, связанным с этим, посвящена диссертация Р.Л.Ковнер «Наречие в современном английском языке».

Зарубежные исследователи английского языка выделяют в этом языке наречие в качестве самостоятельной части речи, однако самостоятельный статус ими определяется по-разному.

Ранние грамматисты, например, Г. Гунт, причисляли наречия к разряду частиц, куда входили все неизменяемые части речи. О. Есперсен также относит наречия к общей группе частиц. Б. Стренг определяет наречие как глагольный адъюнкт. Ч. Фирз включает наречия в класс 4, причисляя, таким образом, к знаменательным частям речи.

Советские исследователи английского языка (А.И. Смирницкий, Б.И. Ильин, Б.Я. Плоткин, А.С. Бархударов) также рассматривают наречие в системе знаменательных частей речи.

Характеризуя наречие как часть речи, необходимо, прежде всего, указать, чем оно отличается от других разрядов слов. В этой связи в первую очередь следует подчеркнуть, что наречие не обладает единым лексическим значением, как другие части речи.

Таким образом, вышесказанное показывает, что в русском и английском языках категория наречия выделяется как часть речи в составе знаменательных слов. Необходимо также отметить, что, несмотря на значительные структурные расхождения обстоятельственных слов в рассматриваемых языках наречия, образованные от прилагательных, наречия образуются от прилагательных при помощи суффикса ly: slow - slowly, careful - carefully; хороший - хорошо, поздний - поздно и др.

${ }^{1}$ Mavzuna ABDUVOHIDOVA, Senior teacher, of the department of the English language under the Tajik State University of Law Business and Politics, Tajikistan. 
В то же время следует отметить, что в английском языке расхождения между частями речи обнаруживают менее отчетливо, чем в языках флективного строя. Говоря о грамматической характеристике частей речи, следует подчеркнуть, что их морфологические признаки и синтаксические отношения играют одинаково важную роль. Но как отмечает А.И. Смирницкий, «синтаксическая сторона является более общей и занимает первое место в грамматической характеристике слова. Так морфологически неизменяемые слова, например, междометия и наречия, выступают как разряды слов, имеющие разную грамматическую характеристику, именно в плане синтаксическом». [3, с.78]

В английском языкознании нет единого мнения о наречии как части речи. Дело в том, что в морфологическом плане английское наречие чётко не отделяется от других разрядов слов, и только в синтаксическом плане оно получает свою грамматическую характеристику. Видимо, поэтому некоторые специалисты склонны не выделять наречие в качестве самостоятельной части речи.

Обычно к наречиям относят слова типа «тогда», yesterday-вчера-дина и др., с одной стороны, и слова типа greatly-очень - хело, quickly-быстро - тез и т.д. - с другой. Слова первой группы называются обстоятельственными, а слова второй группы качественными наречиями. Действительно, в английском нет твердо сложившихся морфологических признаков наречия как части речи. Это объясняется тем, что наречие как категория позднего явления соотносится с именами и глаголами, то которых они образованы и за счёт которых и в настоящее время пополняются.

Хотя наречий времени в сопоставляемых языках довольно много (около 250 единиц вместе взятых), однако они представляют собой группировки слов, весьма ограниченные в плане семантических возможностей обозначения времени, кроме того, практически не пополняемые новыми лексемами. Некоторые исследователи русского языка, говоря о количестве наречий времени, называют цифру примерно в 500 единиц. К наречиям времени они относят все лексемы, которые так или иначе оказываются значимы в плане проявления категорий времени, вида глагол особа разворачивания действия (темп, длительность, кратность и т.п.): быстро (долго работал, ежегодно ездишь). [2, с.117]

Особенность наречия как морфологической формы такова, что она оказывается весьма чувствительной к типу обстоятельственных указаний, выражая более или менее свободно. «Происходит заметное ослабление продуктивности обстоятельственных наречий; это в значительной степени связано с развитием системы вторичных предлогов, которые более дифференцированно выражают обстоятельственные отношения; продуктивность определительных наречий усиливается» [6, c.154].

Рассмотренные разряды наречий, за исключением наречий меры и степени, - это разряды, главное свойство которых состоит в том, что они при глагольные, т.е соответствуют содержанию самого термина, обозначающего данную часть речи, наречие. Что касается употребления наречий в функции определения (не «определения» к глаголу, а определения к существительному, собственно определения), то для наречия эта функция вторична, ибо, видимо, нет ни одного наречия, которое употреблялось бы только в этой функции. Вторичность в данном случае показательно в том плане, что лексема - наречие, употребляемая в функции, а в рамках других функций, свойственных наречиям. Это означает нецелесообразность выде- 
ления в качестве самостоятельного разряда наречий-определений. Из этого, впрочем, не следует, что функция определения может игнорироваться при интерпретации наречий как части речи.

\section{References:}

[1] Аракин, В.Д. Сравнительная типология английского и русского языков - Л: Просвещение, 1979. - 259C.

[2] Васильев, Л.М. Современная лингвистическая семантика. - М.: Высшая школа, 1980, - 175С.

[3] Воронцова, Г.Н. 1960. Очерки по грамматике английского языка. - М: 396С.

[4] Джамшедов, П. 1974. Таджикско-английские соответствия (разряды глагола). Изд-во Минвуза Тадж. ССР, 88С.

[5] Ильиш, Б.А. Современный английский язык. М., 1948.

[6] Мюллер, В.К., Дашевская В.Л., Каплан В.А. и др. новый англо-русский словарь: Ок. 60000 слов /В.К. Мюллер, В.Л. Дашевская, В.А. Каплан. - М.: Рус. Яз. 1994, 880С. 


\section{THE IMPORTANCE OF SOCIOLINGUISTICS AS A LINGUISTIC DISCIPLINE}

1B. Kushakova

\section{Abstract}

The article highlights the importance of sociolinguistics as a separate science which studies the relationships between language and society. It focuses on the discussion of key issues studied within the framework of sociolinguistics.

Key words: sociolinguistics, language, society, social factors, external conditions.

The term "sociolinguistics" can be interpreted in two senses in modern linguistics: a) A sense referring to the fact that language cannot be without a society and society cannot be without a language; and b) An inference referring to the differences relating to the social grouping of nation in language.

It is noted that there has been appeared a new linguistic discipline as a science in the field of general linguistics which can reinforce the opportunity to study the relationships between language and society. This phenomenon is conditioned by the interest to the social nature of language in France. The work written under the influence of "Marxism" by Poll Lafarg was the first work referring to the interrelation between society and language at that time.

In order to reveal the significance of sociolinguistics as a linguistic science, it is vital of importance to point out the general problems of sociolinguistics suggested by A.A. Abduazizov and et al., they are the following concerns ${ }^{2}$ :

1) The functional-typological classification of languages and its role in other classifications;

2) Oral and written literature (sciences of philology) and the theory of sociolinguistics (as a plan of the interrelation between the theory of language and the practice of sociolinguistics);

3) Sociolinguistics in language ontology;

4) The socially needed problem of language in the history of linguistics, linguistic axiology and sociolinguistics;

5) The typology of the language situations;

6) The problem of scientifically managing language life;

7) Society;

8) The development of language from sociolinguistic point of view. Social factors have a significant influence on the formation, movement and typicality of social-political terminology and lexemes, the effect can be both natural and cognitive in this process.

In addition, as stated by 0 . Azizov, a well-known linguist, the importance of sociolinguistics can be determined by the following functions it should do: a) it should learn the existence and the movement needs of national-literary languages. This is the most urgent issue requiring the attention of philosophers, historians and literature executives; b) it should

\footnotetext{
${ }^{1}$ Barno Kushakova, UzSWLU, Uzbekistan.

${ }^{2}$ Abduazizov A.A. Sodikov A.C. Iriskulov M.T. Introduction to Linguistics. T.: «O’qituvchi».1981.-p, 226.
} 
learn the influence of social factors on not only the external structure of language, but also the internal structure of language ${ }^{1}$.

J.Vandries, in his book "Language", wrote: "the problem of language origin does not belong to linguistics". However, it is the truth. Linguist always works with the organism which has already been created by several generations. The origin of language is out of its investigation field. In fact, as A.T. Basiev claims, this particular problem merges into the problem of human origin and human society. This belongs to the history of ancient time of human society. Language appeared as soon as the human mind development and human society had appeared ${ }^{2}$

The importance of sociolinguistics as a science can be notified by the fact that the importance of language is very high in the social life. Language is a social phenomenon that was created by the whole society and its members in all historical stages of human society. Language has been the most important means of communication during the historical development of human society and there have been a lot of different notions, opinions and theories about its features. Language is closely connected with human activity and the development of human society. It is impossible to consider it as a phenomenon that has no any relationship with society and the history of human brain.

Today, the following conclusions can be drawn about the problems solved by sociolinguistics as a linguistic science:

$>$ the development of society has caused to expand the social functions of languages;

$>$ the lexicography of all languages increases and exceeds;

$>$ the processing of the social development has an effect on literary languages;

$>$ the influence of languages to one another, those of neighbouring nations increases;

$>$ the social role of the language which serves as a means of international communication increases and its influence on other languages also rises;

$>$ bilingualism develops;

In conclusion, it can be highlighted that sociolinguistics investigates the most important aspect of language- language is a social phenomenon- the dependence of language on society and the communicative function of language.

\section{Reference:}

[1] Abduazizov A.A. Sodikov A.S. Iriskulov M.T. Introduction to Linguistics. T.: «O'qituvchi».1981.-p, 226.

[2] Azizov 0. Introduction to Linguistics.T.: "O'qituvchi"1996.-p,176.

[3] Basiev A.T., Isaev M.I. Language and Nation. M.: «Nauka», 1973.

\footnotetext{
${ }^{1}$ Azizov O. Introduction to Linguistics.T.: "O'qituvchi"1996.-p,176.

${ }^{2}$ Basiev A.T., Isaev M.I. Language and Nation. M.: «Nauka», 1973.
} 


\section{MORPHOLOGICAL FEATURES OF THE VERBAL PHRASEOLOGICAL UNITS}

1D. Majidova

\section{Abstract}

The article is devoted to the study of the morphological features of verbal phraseological units. Verbal phraseological units, like simple verbs, signify the action state and other processes, performing in the sentence primarily the syntactic function of the predicate. Forms, although the corresponding structural types of variable word combinations are not limited in the choice of word forms that are part of them.

Keywords: morphology, verb meaning, lexical and grammatical aspect, analysis, comparisons, component, idioms.

Рассматривая глагольные фразеологизмы как семантически целостные состоящие из двух и более знаменательных в данной конструкции неразрывно связанных слов имеющие четкую систему моделей определенный набор морфологических категорий своеобразную парадигматику отражающую специфику семантической структуры этих единиц. В контакте глагольные фразеологизмы актуализируются как минимальные единицы коммуникации которые совместно с реализуемыми валентностями составляют особые конфигурации отражающие регулярно воспроизводимые фразеологические связи $[3,98]$.

Глагольные $Ф Е$ как и простые глаголы обозначают действие состояние и другие процессы выполняя в предложении прежде всего синтаксическую функцию сказуемого. Обладая подобно лексическим единицам определенными грамматическими категориями фразеологизмы реализует их в формальных показателях в структуре слова однако основным реализатором грамматическихкатегорий и внешних структурных показателей ФЕ является стержневое слова глагол который выступает не только семантическим но и своеобразным ядром фразеологизма. При этом если исходить из того во внешней связи ФЕ в строе предложения решающим становится её структурные связи внутри языковой единицы благодаря которому ФЕ приобретает важнейший признак- признак раздельнооформленности. Конкретная их форма и лексико-грамматическоесодержаниезависит прежде всего от лексикограмматического типа слова и реализации функциональных возможностей ФЕ в реальных ситуациях. Как и во всей системе фразеологии в глагольных фразеологизмах грамматические формы компонентов могут так или иначе меняться при этом грамматически зависимые компоненты изменяют эти формы очень ограниченно в то время как стрежневые компоненты изменяются значительно свободнее. Особенно это касается такого структурно-морфологически развитого разряда слов как глагол отличающегося от других лексико-грамматических разрядов слов а сопоставляемых языках наибольшей представленностью грамматических категорий и способов их формально -грамматического и словообразовательного выражения в структуре самого слова $[4,98]$.

Отражая категориально-грамматическое особенности стержневого компонента глагольным фразеологизмам свойственны теже грамматические категории которые составляют основные грамматические признаки глагола как лексико-грамматического класса слов в языке. Это такие категории как залог наклонение время лицо число и условно категория рода. Формальным показателем той или другой категории служит грамматически опорный компонент-глагол являющийся семантическим и структурно-грамматическим центром фразеологизма.

1 Dilorom MAJIDOVA, associate professor of the department of English language, under the Tajik State University of Law, Business and Politics, Tajikistan. 
Характерной особенностью ГФЕ является формоизменение глагольного компонента.В то же время следует отметить что подавляющее большинство глагольных Фе ограничены в варьировании слово -изменительных форм. Отсутствие свободного употребления и реализации грамматических форм и целом является закономерностью для всех языковых единиц. Поэтому не только фразеологизмы, но и многие слова не способны реализовать все возможные и допустимые грамматические формы, хотя соответственные им структурные типы переменных словосочетаний не ограничены в выборе словоформ, входящих в их состав. Несмотря на фактическое совпадение структурных особенностей фразеологизмов со свободными словосочетаниям, по структурной схеме которых они строятся, морфологические формы компонентов фразеологизма не имеет возможности копировать морфологические формы, являющиеся спецификой слов в составе переменных словосочетаний. сравните, с точки зрения формообразования глагол рullв составе фразеологизма pull smb.s leg [букв; тянуть чью-л.ногу ]-касеро ањмак кардан "одурачивать кого-л., морочить голову"-допускает употребление во временных формах; Present Continuous.Present Perfect continuous.Past continuous.Past Perfect Continuous.Past Perfect [Passive Voice].Как показывают материалы нашего исследования и статистические данные, указанные выше формы являются самыми продуктивными в функционировании ФЕ в языке. Употребление глагола в данной ФЕ преимущественно ограниченно несколькими формами, тогда как в качестве самостоятельного слова в повседневной речи глагол pull может употребляться во всех формах и приведения форма повелительного наклонения обычно допускается только в отрицательной форме; don't pull my leg. You went to the theatre/-сарамро гаранг накун- "Не морочь мне голову. Ты ходил в театр". [1,5, 74-96].

То же самое касается и структурно-грамматического функционирования других глаголов в составе ФЕ. При этом не является обязательным ограничение только в вышеназванных формах. Круг временных форм может быть другой, но ограничение определенным составом временных форм может быть другой, но ограничение определенным составом временных форм действует при использовании всех глаголов в ФЕ. Оно может охватить разные количества глагольных форм и разных групп самих глаголов. Если в одних случаях для глаголов употребление формы страдательного залога является строго обязательным и фактически единственно допустимым, то в других глаголов не допускает употребление данной формы. Сравните еще примеры дифференцированного употребления залоговых форм глагола в глагольных фразеологизмах, при котором особенности субъектно-объектных отношений обусловливаются реалиями действительности и осмыслением соотношения действия и субъекта и объекта действия. Исходя из этого, только в страдательном залоге употребляются глаголы в следующих фразеологизмах: be gathered to one's fathers -ба пеши гузаштагон рањсипор гаштан. [букв. присоединиться к своим отцам]- «отправиться к праотцам, скончаться»; be thrown on one's beam-ends-ба пањнои зиндагї афтидан [букв: быть брошенным на балки] «быть в тяжелом, безвыходном положении» (первонач. о судне: «лежать на боку») bebornonthewrongsideoftheblanket [букв: родиться не на той стороне одеяла] «быть незаконнорожденным» - бачаи ѓайриќонунї таваллуд шудагї $[8,105]$.

References:

[1] Азимова М.Н. Сопоставительный анализ фразеологических параллелей английского и таджикского языков. Душанбе, 1999. 115 с.

[2] Баракаева Г.Б. Принципы составления таджикско-английского словаря и вопросы таджикско-английской лексикографии. АКД, Душанбе, 1968-24с.

[3] Кунин А.В. Английская фразеология. Теоретический курс.- М. Высш. Шк. 1970-344с.

[4] Сазонова М.К. Лексика и фразеология современного русского языка. 1963. 
[5] Хасанов И. Лексика ва фразеологияи романи «Дохунда»-и С.Айни. Душанбе Ирфон 1974$157 \mathrm{c}$

[6] Oxford Dictionary of Current Idiomatic English. Vol.2. - Oxford University Press, 1988.

[7] Oxford Idioms Dictionary for learners of English. OxfordUniversityPress, 2003.

[8] Амбражейчик А. 2000 русских и 200- английских идиом, фразеологизмов и устойчивых словосочетаний/А. Амбражейчик. - 2-е изд. -Мн.: 000 «Попурри», 2005.

\section{THE VALUE OF MATCHING PREPOSITIONS IN ENGLISH AND TAJIK LANGUAGES}

\section{${ }^{1}$ M. Mirzojonava}

\section{Abstract}

The article discusses the meaning of the prepositions English and Tajik languages, which express local meanings. The functions of prepositions that express the basic relations between the members of a sentence and the components of word combinations are considered. On the basis of the value of space and movement, numerous, generally homogeneous abstract values arose that have not lost their obvious connection with the primordial concrete.

Keywords: express, relationship, preposition, local, meaning, point, initial, point, action.

Предлоги в сопоставляемых языках являются словами, которые не только указывают на наличие известных отношений между «знаменательными словами» в предложении, но при помощи своих значений раскрывают и уточняют содержание и характер этих отношений. Роль предлога не исчерпывается формальной синтаксической функцией указывания, какое слово грамматически подчинено другому. Очень велика семантическая роль предлога, сообщающего отдельному словосочетанию (а через него часто и всему предложению) свое значение, которое конкретизирует и обогащает отношения «знаменательных слов» между собою.

По структурным свойствам предлоги делятся на простые в таджикском языке они называются пешояндхои содда, которые чаще всего состоят всего из одного слога такие как дар, барои, ба, бо имеющие в английском языке значение, -in, on, at, for, with. Сложные предлоги таджикского языка называются пешояндхои мураккаб, которые состоят более, чем из одного слога, иногда даже из нескольких отдельных элементов такие как дар тарафи, дар беруни, дар дохили имеюшие в английском языке значение inside, outside, within). Составные предлоги таджикского языка называются пешояндхои таркиби аз сабаби, дар ру ба руи - because of in front of in accordance with. С точки зрения морфологического состава основное ядро предлогов составляют простые, часто односложные, неразложимые слова. Сюда относятся такие предлоги, как in, on, for, by, at, of to, with, over, under, against к ним относятся предлоги таджикского языка такие как дар, дар руи, барои, бо, дар назди, аз, ба, аз болои, дар зери и т.п. Эти предлоги очень давно существуют в языке и участвуют в образовании различных позднее возникших предлогов [1].

В составе предлогов английского языка имеются слова, образованные с помощью префиксов, например: behind, below, across, along, или путем словосложения например: without, inside, но эти способы образования предлогов давно перестали быть продуктивными. Предлоги типа regarding, concerning, considering - производные по

${ }^{1}$ Malika MIRZOJONAVA, candidate of philology, Associate Professor, Tajik State University of Law, Business and Politics. Tajikistan. 
своей морфологической структуре, но выделяемый в этих словах суффикс - ing не является и никогда не был словообразующим для данной части речи. Этот суффикс закономерно обнаруживается в составе предлогов, семантическим путем развивавшихся из причастий, и потому только служит показателем генетической связи предлогов с данной глагольной формой.

Продуктивным способом образования новых предлогов для английского и таджикского языков можно считать синтаксический, но не путем словосложения, а путем образования составных предлогов. Составные предлоги образуются из сочетаний: 1) двух предлогов: out of, from behind; в таджикском: аз дохили, аз паси 2) предлога с существительным и предлогом in spite of in view of; в таджикском: аз даруни, аз беруни, аз болои; 3 ) союза с причастием или прилагательных и предлогом или союзом: as compared with, as far as ; 4) прилагательного или причастия - иногда наречия или союза - с предлогом: previous to, owing to, because of apart from и т.п.

Из перечисленных структурных типов первый (from behind) включает предлоги, служащие для выражения пространственных отношений, тогда как остальные (типа in spite of и др.) чаще всего передают разнообразные логические отношения, связанные со значением знаменательного слова, входящего в данный составной предлог (with respect to, as compared to).

Первообразные предлоги, имеющие пространственные значения, следующие: on, to, in, by, of- дар, ба, аз.

Современная система предлогов английского языка остается по преимуществу древнеанглийской, поскольку ни завоевания, ни заимствования не оказали на нее заметного влияния через посредство иммигрантов, торговли, войн и литературы не оказали на нее заметного влияния. За исключением предлогов английского языка afore и не часто употребляемого underneath, остальные 38 древних предлогов английского языка about, afore, after, along, amidst, at, before, beneath, but, by, for, from, in, into, near, of, on, out of over, through, till, to, towards, under, underneath, with, without. Другие 12 предлогов- above, against, among, behind, beside, beyond, next, throughout, until, up, within -засвидетельствованы в литературных памятниках периода от 1000 до 1200 г. являются общеупотребительными в современной литературе и в разговорной речи [4].

В современном языке древнеанглийские и латино-французские предлоги образуют систему из 121 слова.

Сюда входят:

1) простые предлоги типа at, in, from, for, under, on;

2) сложные типа within, from, outside, beyond, upon, throughout;

3) причастные типа during, concerning, past, except.

К этому ряду примыкает категория составных предлогов (число их неопределенно - около 280) типа by means of, thanks to, abreast of, with reference to, prior to, on account of, in spite of.

Значение предлогов этих разрядов для языка неодинаково. Эти предлоги часто образуют лексические сращения с глаголами (реже - с существительными) и участвуют в образовании сложных и составных предлогов [2].

Сложные предлоги, как правило, появились в результате потребности выразить двойные пространственные, точнее: пространственно-моторные отношения (вроде: «из-под», снизу на», «из-за»; from below, inside, underneath, upon). Причастные предлоги, по-видимому, возникли в результате двойного сжатия придаточных предложений: их сказуемое превратилось в причастие, а последнее - в предлог. Это 
численно наименьшая и исторически самая молодая группа целиком состоит из предлогов с отвлеченным смысловым содержанием: 9 со значением «за исключением, кроме», 6 - со значением «относительно, касательно», 3- временных.

Составные предлоги образовались из различных предложных словосочетаний, знаменательная часть которых (существительное) в значительной степени утратила свое вещественное значение и формализовалось. В одних случаях значение этих слов еще достаточно ясно (by way of - дар даруни, дар беруни), но в других оно затемнено (by virtue of in spite of). Составные предлоги в известной мере являются надстройкой над основной системой предлогов и лишь немногие из них являются общеупотребительными в разговорной речи [3].

\section{References:}

[1] Аксененко Б.Н. Предлоги английского языка / Ред. Е.И. Аничков-М.: Изд-во лит. на иностр.яз., 1956.-320с.

[2] Аракин В.Д Исследования по сопоставительной типологии языков /Межвуз. сб.науч.тр. Моск. гос. пед.ин-т им. В.И.Ленина. - М., 1982. - 165 с.

[3] Бурханова Г. Сопоставительный анализ составных предлогов с пространственным значением в английском и таджикском языках. -Душанбе, 2005.

[4] Джамшедов П. Таджикско-английские соответствия (разряды глаголов). - Душанбе, 1974.

\section{PROVERBS AND SAYINGS IN TAJIK AND ENGLISH LANGUAGES}

\section{Z. Pulatova}

\section{Abstract}

The article deals with the role and place of proverbs and sayings in the Tajik and English languages. Revealing the role and place of proverbs and sayings in the language system, the author believes that it reflects the present and the past, the state of the people and the proverbial wisdom. Over the long years of its existence, humanity, based on its concrete life experience, has created a large number of proverbs and sayings that have gradually spread among people. Thus, proverbs and sayings hide the long-term experience of mankind.

Keywords: proverbs and sayings, language, short folk expressions, non-standard expressions, wisdom of the people, folklore, folk art, general speech, development of culture, historical path.

Общество нельзя представить без языка. Язык - это зеркало образованности, общей культуры народов. В нем находит свое отражение настоящее и прошлое, состояние науки и народная мудрость. Являясь одним из видов народного фольклора, пословицы и поговорки, начиная ещё с древнейших времен, развивались в тесном контакте с другими подобными проявлениями художественного жанра, например, такими как наставление, загадка, анекдот, притча и т.п.

В лингвистическом энциклопедическом словаре дано такое определение пословицы: Пословица - краткое, устойчивое в речевом обиходе, как правило, ритмически организованное изречение назидательного характера, в котором зафиксирован многовековой опыт народа, имеет форму законченного предложения (простого или сложного). Поговорка - это краткое изречение, нередко назидательного

1Zamira PULATOVA, Senior teacher of the department of English language under the Tajik State University of Law, Business and Politics, Tajikistan. 
характера, имеющие в отличие от пословицы, только буквальный план и в грамматическом отношении представляет собой законченное предложение.

На протяжении долгих лет своего существовании, человечество на основе своего конкретного жизненного опыта создало большое множество пословиц и поговорок, которые постепенно распространились среди людей. Таким образом, в пословицах и поговорках скрыт многолетний опыт человечества. Здесь будет уместным привести слова М.А.Шолохова, сказанные по данному поводу: «Величайшее богатство народа - это его язык. На протяжении тысячелетий, слово служило вечным и бездонным хранилищем, в котором постоянно накапливались мысли и опыт людей. Пословицы и поговорки - это то, дошедшее до нас достояние, которое при грамотном использование, способствуют более точной передачи мысли. С древних времен люди использовали пословиц: Трусливая собака громче лает, чем кусает. The cowardly dog barks stronger than bites. Овози саги тарсончак аз газиданаш сахттар аст. Самая глубокая река та, которая постоянно течёт. Чукуртарин дарё хамон аст, ки хамвора чори бошад. The deepest river is the one that constantly flow.

Таджикский фольклор с древних времен был достаточно хорошо знаком с жанром пословиц и поговорок. Начиная с древних времён, этот жанр играл заметную роль в формировании и развитии культуры таджикского народа. Данный факт был глубоко и обстоятельно исследован в труде И.С. Брагинского «Из истории таджикского народа». Пословицы и поговорки на различных этапах истории отражали господствующую на тот момент идеологию различных классов. Посредством пословиц и поговорок, как в зеркале отражалась борьба разных групп. Пословицы и поговорки в краткой, сжатой форме отражают глубокие и мудрые народные изречения. Посредством умелого употребления пословиц и поговорок язык либо писателя, либо оратора становится более выразительным и содержательным. Творцом формы этих изречений является народ. Такие изречения делают язык - сладким, мысль светлой, ясной, привлекательной, они дополняют речь, делают её значимой, стилистически окрашенной. Во все времена и эпохи пословицы и поговорки представляют собой жемчужину народной мудрости. Они используются писателями и поэтами.

Общеразговорная речь сильно отличается от своей литературной формы. Хотя пословицы и поговорки являются продуктом устного народного творчества, тем не менее, их грамматическая структура отлична от общепринятых разговорных форм. Одам аз хок аст, кай монад ба хок? Хеч ангуре намемонад ба ток. Adam is made of earth, but how should he resemble earth? No grape resembles the vine. Every bullet has its billet. Хар камолеро заволе. Одам дубор ба дунё намеояд. От судьбы не уйдешь. Некро неки бувад, бадрост бад. Му Law does not turn aside from rectitude; good shall be fall the good, evil the evil. To pay one back in one's own coin. Ба неки неки, ба бади бади. Платить кому-либо его же монетой [8].

Общеизвестно, что главным источником появления и последующего развития народного творчества, как в таджикско-персидской, так и в западноевропейской среде, является сам народ, его бесконечно долгий опыт бытия, который способствовал появлению и развитию различных видов паремий. Кроме того, необходимо сказать, что пословицы и поговорки являясь первоначально чисто устным видом народного творчества, со временем обретают свою книжную форму, и в определенной мере стабилизируют свою грамматическую структуру. От доброго честь, от злого - беда. Аз хубон шарофат, аз бадон касофат. Evil communication corrupt good manners или Чангал бедангал намешаваду диёр бедушман. Гушт беустухон намешавад. Нет розы без шипов, пчелы без жаль. Every white has its black and every sweet its sour [3]. 
Большинство пословиц и поговорок разных народов по основе своей специфике достаточно схожи между собой. Например: английская пословица

A burnt child dreads the fire, Моргазида аз ресмони ало метарсад. Ожегшееся дитя огня боится [5].

Основным источником появления и распространения народных пословиц и поговорок, как в персидско-таджикской, так и в английской литературе, было долгое фактическое наблюдение за социально-культурной жизнью народа и на основе этих наблюдений постепенно возникли самые разнообразные пословицы и поговорки. Важным является то, что в народной среде большое количество пословиц и поговорок относятся к проявлениям фольклора. Пословицы и поговорки, являясь одним из лучших творений народа, требуют к себе особо пристального внимания. Это бесценные жемчужины, отшлифованные временем и вобравшие в себя философию наших предков. В общем, пословица - это краткое народное выражение, которое обычно используется в разговорной речи.

\section{References:}

[1] Амосова Н.Н. Основы английской фразеологии/Н.Н.Амосова.-Ленинград:ЛгУ,1963.

[2] Виноградов В.В. Об основных типах ФЕ в русском языке /В.В.Виноградов// Лексикология и лексикография. Избранные труды. - Москва: Наука, 1977.

[3] Джалилов Х. Структурно-семантические особенности и синтаксические функции фразеологических единиц в современном таджикском современном языке/Х.Джалилов.-Душанбе.

[4] Кунин А.В. Курс фразеологии современного английского языка/А.В.Кунин.-Москва, 2005.

[5] Пермяков Л.П. Избранные пословицы и поговорки народов Востока /Л.П.Пермяков.

[6] Ярцева В.Н. Большой энциклопедический словарь/В.Н.Ярцева//Москва: Большая Российская энциклопедия.

[7] Teylor A. The Proverbs and the Index to the Proverb /A.Teylor. - Copenhagen.

[8] Collis H.101 American and English Proverbs /H.Collis. - Chicago, 1975. 


\section{MEDICAL SCIENCES}

\section{ANALYSIS OF CONCOMITANT CHANGES IN VISUAL ORGANS AND ORGANISM IN CATARACT WITH ANTERIOR MICROPHTHALMOS}

${ }^{1}$ D. Karimova, ${ }^{2}$ L. Babadzhanova, ${ }^{3}$ N. Umarova, ${ }^{4}$ A. Berdaliev

\section{Abstract}

Microphtalmia is an eye abnormality that arises before birth. Concomitant pathology in inborh cataracts with microphtalmia is considered $37-77 \%$ in such a cases (strabismus, nistagm, microcornea, glaucoma and other).

Children with microphtalmia may also have the greatest eye abnormalities, such as: increase in thickness of cornea (90\%), shortening the palpebral fissure (87\%), strabismus (80\%), hypoplasia of optic disk (70\%), flatness of the lower arch of the conjunctiva (67\%), upper eyelid hypoplasia (57\%), stiff pupil (55\%).

Complex approach in examination of patients with microphtalmia to allowed considerably decrease the possible complications with active surgery and their accompanying changes.

Key words: microphtalmia, microcornea, concomitant pathology, anomalies, frequency of occurrence.

Actuality: Microphthalmos is a congenital intrauterine anomaly of the development of the eyeglass. Concomitant pathology in congenital cataracts with microphthalma is 37$77 \%$ of cases (strabismus, nystagmus, microcornea, glaucoma, etc.)

Purpose: To analyze the occurrence of concomitant changes in the organ of vision and the body in cataracts on the microphthalmic eye.

Material and methods: Twenty children with cataracts were examined at the anterior microphthalmos on 38 eyes. One-sided anterior microphthalmos is observed in 12 (60\%) children, bilateral in $8(40 \%)$ children. The age of the children was from 6 months to 11 years.

The main methods of examining patients with anterior microphthalmos is an external examination, in which the size of the eye gap and orbit, the size and shape of the eyelids, the size and shape of the conjunctival cavity, the size and condition of the reduced eyeball during its visualization are estimated. Also, traditional methods of examination were performed for all children: ultrasonic research involving the measurement of eye APS, Bscanning of eyes and orbits, Visionometry, biomicroscopy, gonioscopy, tonometry, keratopachimetry, CT orbits and skulls, dopplerography of orbital vessels and, if necessary, consultation of related specialists.

\footnotetext{
${ }^{1}$ Dinara KARIMOVA, Pediatric Medical Institute of Tashkent.

${ }^{2}$ Lola BABADZHANOVA, Pediatric Medical Institute of Tashkent.

${ }^{3}$ Naima UMAROVA, Pediatric Medical Institute of Tashkent.

${ }^{4}$ Abbos BERDALIEV, Pediatric Medical Institute of Tashkent.
} 
Results and discussion: At the examination of 20 (38 eyes) children the presence of concomitant pathology was revealed: a shortening of the eye gap in $87 \%$ (33 eyes.), Hypoplasia of the upper eyelid in $57 \%$ (22 eyes.), Trichiasis in $8 \%$ (3 eyes.) the eyelid turn of $6 \%$ ( 2 eyes.), the smoothness of the lower arch of the conjunctiva in $67 \%$ (25 eyes.), the orbit flattening in $48 \%$ (18 eyes.), blepharophimosis was noted in 3\% (1 eyes.), the thickness of the cornea increased $90 \%$ (34 eyes.), Strabismus in $80 \%$ (30 eyes.), Nystagmus in $58 \%$ ( 22 eyes.), Rigid pupil in $22 \%$ (8 eyes.), Glaucoma in 3\% ( 1 eyes.), Coloboma iris in $4 \%$ ( 2 eyes.), choroid in 15\% (6 eyes.), sclerocornea in 2\% (1 eyes.), primary persist ruyuschee vitreous $2 \%$ ( 1 eyes.). Hypoplasia of the optic disc and macula in $70 \%$ (27 eyes)

Visual acuity averaged from 0.06 to 0.4 in 12 children (60\%), from 0.08 to 0.6 in 8 children $(40 \%)$, biomicroscopy revealed various corneal cataracts in $3(15 \%)$, Hypoplasia of the iris in $6(30 \%)$, aniridia in $2(10 \%)$, rigid pupil in $11(55 \%)$, coloboma of the choroid in 1 $(5 \%)$, IOP increase was observed in $1(3 \%)$. Keratopachimetric study revealed an increase in the thickness of the cornea in $18(90 \%)$ children.

Somatic concomitant pathology: CHD in $2(10 \%)$ children, central nervous system damage, cerebral palsy in $3(15 \%)$, congenital toxoplasmosis in $2(10 \%)$, muscle atony in 1 (5\%), microcephaly in $1(5 \%)$ children. When examining the etiologic factor, the mothers of the children examined had some infections or a symbiosis of them, which could have caused the formation of anterior microphthalmus: the herpes simplex virus was found in $7(35 \%)$ mothers, cytomegalovirus in $5(25 \%)$, toxoplasmosis in $210 \%)$, ureoplasmosis in $1(5 \%)$, rubella virus in $1(5 \%)$, chlamydia - in $1(5 \%)$ of the mother.

\section{Conclusions:}

1. When examining the etiologic factor, TORCH infection is the most common among the causes.

2. Frequency of occurrence of such anomalies as an increase in the thickness of the cornea (90\%), shortening of the eye gap (87\%), strabismus (80\%), hypoplasia of the DZN (70\%), smoothness of the lower arch of the conjunctiva (67\%), hypoplasia of the upper eyelid $57 \%)$, a rigid pupil (55\%).

3. The complex approach in the examination of patients with microphthalmos will significantly reduce possible complications with active surgical intervention of their changes. 


\title{
SPREAD OF HCV INFECTION AT DIFFERENT GROUP OF CHILDREN AND ADULTS
}

\author{
M. Boboyev ${ }^{1}$, M. Madumarova ${ }^{2}$
}

\section{Abstract}

The volume of VHC and its genotypes spread among healthy children and adults are established, as well as various groups of risk of sickness with virus hepatitis at people living in the hyper endemic zone of Fergana valley were determined.

High rate of revealing anti-VHC has been found. High level of carrier was marked at groups of patients in resuscitation department and the cadre donors.

Key words: vital hepatite, marker, donor, hepatite.

Введение. Во многих регионах мира складывается неблагополучная ситуация по парентеральным вирусным гепатитам (ВГ). По данным ВОЗ, в мире количество инфицированных вирусом гепатита С (HCV) составляет не менее 500 млн. человек, при этом более 170-200 млн. из них являются больными хроническим гепатитом C (ХГC) $(5,6,7)$. Маркеры HCV - диагностированы у 1-3\% населения земного шара. В CША HCV инфицировано более 4 млн. человек. Эпидемиологическая ситуация по вирусному гепатиту C в Узбекистане также не спокойная $(1,23 * 4,7)$. Страдающие $\mathrm{HCV}$ - инфекцией являются основной причиной развития хронического гепатита, цирроза печени и гепатоцеллюлярной карциномы. При этом в $60-70 \%$ случаев и более исходы данной инфекции, развивающиеся в поздние сроки (спустя 15-25 лет после инфицирования) являются причиной смерти больных. Отсутствие до сих пор специфической профилактики гепатита С, известные сложности лечения определяют сложность и актуальность данной проблемы медицины $(9,12,15)$.

Цель исследования.

Установление широты распространения ВГС и его генотипов среди здоровых детей и взрослых, а также разных групп риска в г. Андижане относящиеся, как и вся Ферганская долина к гиперэндсмической зоне по заболеваемости вирусными гепатитами.

Материал и методы исследования. Под наблюдением находились 977 человек (570 взрослых и 402 детей) составляющие 4 группы. В I группу вошли 260 практически здоровых детей в возрасте от 1 до 14 лет организованные в детские ясли, сады и школы. 2-ю группу составили 104 практически здоровых взрослых, в возрасте 18-50 лет. 3-ю группу составили 471 кадровые доноры постоянно сдающие кровь в станцию переливания крови, г. Андижана. В 4-ю группу вошли 142 детей - пациенты реанимационного отделения, находящиеся там с тяжелыми формами ОКИ, сепсиса и других заболеваний. Обследованные дети и взрослые в указанных выше группах отрицали в анамнезе перенесенные парентеральные вирусные гепатиты.

У всех наблюдаемых наряду с общеклиническими обследованиями проведённого стандартного набора лабораторных исследований, определяли антитела к гепатиту C (анти- HCV) методом иммуноферментного анализа (ИФА)- 3 поколения.

С целые изучения распространения различных генотипов ВГС в г Андижане была

${ }^{1}$ Muhammadayubxon BOBOYEV, Andijan State Medical Institute, Uzbekistan.

2Maxfuza MADUMAROVA, Andijan State Medical Institute, Uzbekistan. 
проведена индикация РНК ВГС методом RT-PCR в сыворотках крови, положительных на анти ВГС с последующим генотипированием выделенных образцов РНК ВГС (лаборатория НИИ иммунологии г.Ташкент). Исследовано 80 образцов по 20 образцов с каждой обследованной группы.

Результаты обследования и их обсуждение. Результаты исследования показали, что в 1- группе практически здоровых детей анти HCV обнаружены у 14 (53\%) а среди обследованных здоровых взрослых у 7 (6,6\%).

Среди кадровых доноров анти HCV выявлены у 90 лица среди больных реанимационного отделения, относящиеся к группе высокого риска анти - HCV выявлен больше всех у $36(25.3 \%)$.

Результаты изучения генотипов ВГС показали, что наибольшее разнообразие генотипов ВГС отмечены в группе пациентов реанимационного отделения, где у $70,0 \%$ выявлен генотип 1 и почти равномерно выявлялись генотипы 1a, 2a. За (соответственно: 10,5; 8,5 и 11\%). А среди кадровых доноров генотип 1в выявлен в $80,0 \%$, генотипы 1а соответственно - 9,5 и 10,5\%.

Среди здоровых детей и взрослых были выявлены только 2 генотипа. Преобладающим генотипом у них был 1в (80,0\% и 90,0\% соответственно). Генотип 1а встречался реже $(20,0$ и $10 \%$ соответственно).

\section{Выводы.}

1.У пациентов с риском парентерального инфицирования выявлена высокая частота обнаружения анти - ВГС.

2.Наиболее высокие показатели выявляются у часто болеющих детей, пациентов реанимационного отделения, взрослых кадровых доноров и сравнительно низкие у практически здоровых детей и взрослых.

3.Высокий уровень носительства и многообразие генотипов ВГС объясняется множественностью источников инфекции, проведенными у них большого количества парентеральных манипуляций, включая переливания крови и ее препаратов по сравнению с группами практически здоровых детей и взрослых.

References

[1] Abdukarimova N. A. The frequency of hepatitis $\mathrm{C}$ infection in various population groups. // Honey. Journal of Uzbekistan - 2000.-№3.-C. 20-22.

[2] Azimov Sh.T., Daminov, T.A..Komilov A.I. Clinical characteristics of circulating genotypes of viral hepatitis C in children. / ${ }^{\wedge}$ Honey. Journal of Uzbekistan - 2000. - №4. - p. 13-14.

[3] Babahodzhaev C.N., Ahmed H.Y., Gulyamov N.G., Khaitov R.Kh. The frequency of detection of markers of HBV, HCV and HiV in blood donors from different regions of Uzbekistan. // Infection, immunity and pharmacy. - 2006. - №5. - pp. 72-73.

[4] Daminov T.A., Azimov S.T. Hepatitis C genotypes in children. // Materials of the VU congress of hygienists, medical doctors, epidemiologists and infectious disease specialists of the Republic of Uzbekistan. - T. - 2000. - p. 188

[5] Lobzin Yu.V., Zhdanov K.V., Volzhanin V.M., Gusayev D.A. Viral hepatitis clinic, diagnosis, treatment - SPb., 2003.'

[6] Mikhailov MI // Viral hepatitis Achievements and Perspekt .: Inform Byul. - 2001. -№ 2 (12). Pp. 8-18

[7] Musabasv IK, Musabaev E.I. Hepatitis C. T. - 2000. - p. 145. 


\title{
THE ESTIMATION OF HEPATIC ENCEPHALOPATHY IN THE PATIENTS WITH HEPATOCIRRHOSIS AFTER PORTOSYSTEMIC SHUNTING
}

\author{
A. Devyatov¹, A. Babadjanov², S. Ruzibaev³, R. Baybekov
}

\section{Abstract}

Observation and treatment results of 490 patients with hepatocirrhosis (HC) in who we have used «HEPAtonormTM - Analyzer» («MERZ», Germany) for complex diagnostics of hepatic encephalopathy (HE) were analyzed. $\mathrm{HE}$ is one of the most frequent complication of HC but its detection frequency can vary from 20 to $80 \%$ subject to the clinical manifestations evidence or instrumental investigations data and it is very important for well-timed introduction of preventive measures into the complex of treatment.

Keywords: liver cirrhosis, portal hypertension, hepatic encephalopathy.

Background. The issues of post-shunting encephalopathy prevention and treatment in modern vascular surgery of portal hypertension are actual, especially for patients after the central total portosystemic shuntings.

Materials and methods. Observation and treatment results of 490 patients with hepatocirrhosis (HC) in who we have used «HEPAtonormTM - Analyzer» («MERZ», Germany) for complex diagnostics of hepatic encephalopathy (HE) were analyzed. The mean age of patients was $28.2 \pm 1.4$ years. Criterion of HE severity estimation before and after portosystemic shunting (PSS) were the results of detection of scintillation critical frequency (SCF) received with the help of «HEPAtonormTM - Analyzer». Scientific principles of this method are detected by $100 \%$ of this machine sensitivity and specificity. All patients were performed elective surgeries: selective shunting (distal splenorenal anastomosis) - 306 (62.4\%); the central PSS - 184 (37.6\%): proximal splenorenal anastomosis with splenectomy - 13 (2.7\%); latero-lateral splenorenal anastomosis - 62 (12.7\%); splenosuprarenal anastomosis - $84(17.1 \%)$; $\mathrm{H}$-shaped splenorenal anastomosis $-25(5.1 \%)$.

Results. In $94(19,2 \%)$ cases of investigated patients group HE was not revealed neither clinically nor instrumentally. In 280 (57.1\%) cases HE was not clinically detected but instrumental investigation allowed to reveal a latent stage of that complication. Clinical manifestations of HE at a primary examination typical for the 1st stage were revealed in $116(23,7 \%)$ patients and it required a performing of preoperational conservative therapy. In the early postoperative period a hepatic failure was noted in $29(11.9 \%)$ patients. Mean index of SCF made up $37.8 \pm 0.9 \mathrm{~Hz}$; indices comparison in patients with normal SCF before surgery and in patients with HE showed a significant difference $(\mathrm{P}<0,001)$ in the progressing level of that complication $(39.1 \pm 1.1 \mathrm{~Hz}$ versus $37.8 \pm 1.1$ and $36.5 \pm 1.2 \mathrm{~Hz}$ ). The introduction of specific conservative measures into the complex of postoperative patients rehabilitation (diet, L-ornitin-L-aspartat, lactulose) allowed to grade HE effects in $59.3 \%$ with the improvement of SCF index up to $38.7 \pm 0.9 \mathrm{~Hz}$. In the

\footnotetext{
${ }^{1}$ Andrey DEVYATOV, Republican Specialized Research Centre of Surgery named after academician V.Vakhidov, Tashkent, Uzbekistan.

${ }^{2}$ Azam BABADJANOV, Republican Specialized Research Centre of Surgery named after academician V.Vakhidov, Tashkent, Uzbekistan.

${ }^{3}$ Sanjar RUZIBAEV, Republican Specialized Research Centre of Surgery named after academician V.Vakhidov, Tashkent, Uzbekistan.

${ }^{4}$ Renat BAYBEKOV, Republican Specialized Research Centre of Surgery named after academician V.Vakhidov, Tashkent, Uzbekistan.
} 
period of 1-2 months after the shunting that index increased up to $41.3 \pm 1.04$ and clinical manifestations of HE were revealed only in $11.1 \%$ of patients, latent form of HE by SCF indices was detected in $35.0 \%$.

Conclusions. HE is one of the most frequent complication of $\mathrm{HC}$ but its detection frequency can vary from 20 to $80 \%$ subject to the clinical manifestations evidence or instrumental investigations data and it is very important for well-timed introduction of preventive measures into the complex of treatment. The detection of SCF limen with the help of «HEPAtonormTM - Analyzer» allows to objectively estimate the severity level and the risk of HE progressing in the patients with HC. So, this complication is revealed in the preoperational period in $80.8 \%$ of patients with $\mathrm{HC}$ and a latent stage - in $57.1 \%$ of cases. In $100 \%$ of cases the operative intervention worsens the index of SCF, the risk of hepatocellular failure development is 2 times higher in patients with HE which clinically or instrumentally revealed before surgery and requires to conduct specific treatmentpreventive measures at all stages of portosystemic shunting. 


\section{TYPES OF ANTERIOR CAPSULORHEXIS USING TREPAN BLUE DYE IN CATARACT EXTRACTION IN CHILDREN}

${ }^{1}$ L. Babadzhanova, ${ }^{2}$ D. Karimova, ${ }^{3}$ M. Mavlanov

\section{Abstract}

The current level of cataract surgery depends on the consistent improvement of the details of the stages of the surgical technique. One of the main ones is the anterior capsulorhexis (AC). The literature indicates a sufficiently large arsenal of types of PC execution ("tin can", "herringbone", linear autopsy, etc.). The growing clinical response of performing ACs led to the same opinion of eye surgeons. Capsulorexis should be perfectly round, smooth, 5.0-5.5 mm in size. Purpose. Analysis of anterior capsulorhexis performed during cataract extraction in children.

Key words: Cataract, trepan blue dye, capsulorhexis.

Актуальность. Современный уровень хирургии катаракты зависит от последовательного совершенствования деталей этапов хирургической техники. Одним из основных является- передний капсулорексис (ПК). В литературе указаны достаточно большой арсенал разновидностей выполнения ПК («консервной банки», «елочки», линейное вскрытие и др.). Растущий клинический ответ выполнения ПК привел к одному мнению офтальмохирургов. Капсулорексис должен быть идеально круглым, ровным, гладким, размером 5,0-5,5мм. Идеально выполненный ПК предупреждает опасность развития в послеоперационном периоде ряд осложнений, которые могут вовлечь за собой снижение функций, ограничивает визуализацию периферии глазного дна, повышение внутриглазного давления и др. неравномерные эластические свойства передней капсулы хрусталика у детей делают невозможным выполнения стандартного непрерывного кругового капсулорексиса во всех случаях.

Цель. Анализ переднего капсулорексиса, выполненного при экстракции катаракты у детей.

Материал и методы исследования. В исследование были включены 20 детей (20глаз) в возрасте от 3 до 7 лет с врожденной катарактой, которые были разделены на две группы. В первую группу были включены 10 глаз, где выполнение ПК без красителя, во второй группе (10глаз) с красителем (1\%трепановый синий). Окрашивание капсулы хрусталика выполнялось по следующей схеме: через боковой парацентез вводился стерильный воздух, затем краситель 0,1-0,2мл. после окрашивания передней капсулы остаток красителя вымывался физиологическим раствором с целью защиты эндотелия роговицы. ПК выполнялся после введения вискоэластика. В первой группе от 10 глаз выполнение ПК удалось на 4 глазах (40\%), на 6 глазах (60\%) произошло «убегание» разрыва к экватору. Во второй группе - на 8 глазах (80\%) удалось выполнить ПК, на 2глазах (20\%) был радиарный разрыв передней капсулы хрусталика.

Вывод. Применение красителя для окрашивания капсулы хрусталика улучшает визуализацию в формировании отверстия ПК, также не вызывает интер- и постоперационных осложнений.

\footnotetext{
${ }^{1}$ Lola BABADZHANOVA, Tashkent Pediatric Medical Institute, Uzbekistan.

${ }^{2}$ Dinara KARIMOVA, Tashkent Pediatric Medical Institute, Uzbekistan.

${ }^{3}$ Murod MAVLANOV, Tashkent Pediatric Medical Institute, Uzbekistan.
} 


\section{ORGANIZATION OF MEDICO-SOCIAL RESEARCHES AND METHODS}

OF THE STATISTICAL ANALYSIS

${ }^{1} \mathrm{M}$. Muyassarova, ${ }^{2} \mathrm{Sh}$. Abdurashitova, ${ }^{3} \mathrm{~F}$. Yuldasheva, ${ }^{4}$ T. Rakhmonov, ${ }^{5}$ M. Makhsumov, 6 U. Tuymachev

\section{Abstract}

The article is devoted to organization of medico-social researches and methods of the statistical analysis.

Key words: medico-social researches, methods of the statistical analysis.

Process of the organization and carrying out medico-social researches consists of 4 stages:

1) development of design of a research;

2) collection of information and formation of databases;

3) processing, analysis and visualization of data;

4) development of administrative decisions, their introduction in practice and assessment of their efficiency.

1 stage - development of design of a research. At this stage the program and the working plan of a research are developed.

The program includes: a research subject, the purpose, tasks, the formulated hypotheses, the name of an object and sampling units, the description of statistical methods of formation of a sample, collecting, storage, processing and the analysis of data, the list of the used statistical tools, the glossary of terms.

The working plan (the annex to the program) represents the mechanism of implementation of the program of a research and includes the list of the main actions: order of selection, training and organization of work of direct performers; development of standard and methodical documents; determination of necessary volume and types of resource providing research (shots, finance, material, information resources, etc.); determination of terms and responsible for separate investigation phases. The working plan is submitted in the form of the network schedule.

Understand some statistical set as an object of a medico-social research.

Statistical set - rather uniform group of sampling units or phenomena which is characterized by existence of some general signs.

Sampling unit - primary element of statistical set allocated with all signs which are subject to studying.

Distinguish the following registration signs of a sampling unit:

- verbal - having descriptive character and expressed verbally;

- quantitative - expressed by some numbers;

- factorial - exerting impact on productive signs;

\footnotetext{
${ }^{1}$ Mukhabbat MUYASSAROVA, senior teacher, Tashkent medical Academy, Uzbekistan. ${ }^{2}$ Sharafat ABDURASHITOVA, senior teacher, Tashkent medical Academy, Uzbekistan. ${ }^{3}$ Feruza YULDASHEVA, senior teacher, Tashkent medical Academy, Uzbekistan. ${ }^{4}$ Tokhir RAKHMONOV, associate professor, Tashkent medical Academy, Uzbekistan. ${ }^{5}$ Muzaffar MAKHSUMOV, associate professor, Tashkent medical Academy, Uzbekistan. 6Ulmas TUYMACHEV, assiatant, Tashkent medical Academy, Uzbekistan.
} 
- productive - depending on factorial signs. The statistical set happens two types: of signs;

- population is a set of qualitatively uniform sampling units united by one or group

- the sample (selection) is any subset of sampling units of population.

Depending on the volume of sampling units it is accepted to distinguish a continuous and selective research. At a continuous research study all units of population, at selective - only her part (selection).

In a concept statistical tools are included: cards, questionnaires, models of tables, computer programs of control of the entering information, formations and processings of information databases, etc. in which enter the studied data.

At the first stage of a statistical research develop models of tables. Distinguish the following types of tables: simple, group and combinational.

2 stage - collection of information and formation of databases. The main sources of information on the state of health of the population are:

- data of the state and departmental statistical observation;

- data of specially conducted selective researches;

- the electronic personified databases of governing bodies of health care, territorial funds of the obligatory medical insurance (OMI), medical insurance companies.

The Database (D) - the data array structured and stored on electronic media which operate by means of the special software - the database management system (DMS).

3 stage - processing, the analysis and visualization of data. Data processing is a process of preparation, group of data, calculation and the analysis of statistics with use of methods of mathematical statistics.

4 stage - development of administrative decisions, their introduction in practice and efficiency assessment. Administrative decisions in health care can be expressed by means of the following legal forms:

- Preparation of drafts of normative legal acts of bodies of legislative and executive power;

- Preparation of drafts of orders of heads of governing bodies and organization of health care;

- Development of methodical recommendations and instructions;

- Development of comprehensive or target medico-social programs, etc. References:

[1] Medic V. A., Yuryev V.K. Public health and health care: textbook. - 2nd prod., reslave. and additional - M.: GEOTAR-media, 2012. 


\section{AXIOLOGICAL ASPECTS OF MIDDLE EASTERN ORIENTAL PHILOSOPHY}

\section{Z. Odinaeva}

\section{Abstract}

This article deals with the axiological aspects of the medieval east philosophy. There are deals with the role and importance of medieval East philosophy in the history of the Oriental Folklore in this article.

Key words: Al-Bukhari, At-Termizi, Kubra, Ahmad Yassaviy, Naqshband, the spiritual and spiritual leaders, such as traditions, ideology, Islam, divine values, axiology, Khorazmiy, Forobi, Beruni, Ibn Sino, Ulugbek.

The term medieval philosophy also reflects the broad, diverse philosophical phenomena, the formation, development, and spiritual-moral influence of routes, both from the essence and from the point of view of the region. First, it is a philosophy that emerged in the Western Europe for centuries in feudalism. Its meaning is directly related to the sociocultural characteristics of society, the active influence of the Catholic Church.

Second, Shark. their peoples also have medieval medieval origins. During this period, Islam was widely entering the life of many peoples in addition to the Arabs and became a stronghold. Gradually, economic, cultural, and scientific ties are rising, interest in the natural world of the ancient world has grown, and aristocracy is widespread. Philosophical thinking developed on the basis of local, ancient world traditions and new ideology.

VIII-XII centuries have great significance in the development of Central Asian values. During this period, the Arab conquest took place, and Islam became an official religion, and there was a certain peace in public life.

Islam has not only become a religion of religion in Asia, it has become a common religion of many Oriental peoples. It must be admitted that the divine values described in the Qur'an have had a profound impact on the history and culture of our peoples. The significance of this influence can be assessed and analyzed, but it can not be denied that it has a certain value in the past. Every scientist, scientist, scientist, and scientist who lives on our land has an influence on the influence of Islamic religious values. At the same time, it should be noted that during the spread of Islam in our country and the Arab identity, many nationalities were lost. In this regard, Beruni wrote with regret in his work "Monuments of ancient folklore".

At the same time, it should be noted again that the values of the civilizations of our Homeland have a great impact on the development of the Arab world. Lecturers such as Khorazmiy, Forobiy, Beruniy, Ibn Sino, Ulugbek, Al-Bukhari, At-Termizi, Kubro, Ahmad Yassaviy, Nakshband, Lutfi, Navoi. Babur, Bedil, Mashrab are not only Islamic, but also the cultural and civilization of civilization. It is possible to carry out special studies on their influence on Islam, its transition to time. It is no surprise that modern Islamic scholars worship Al-Bukhari's works as sacred books after the Qur'an, and worship at the graves of al-Bukhari, At-Termizi, Yassaviy and Naqshband! Despite the fact that the sources are enough, the writings about the influence of the codification of our country on the development of Islamic religion and the evolution of the culture of ancient Islamic countries are still insufficient.

In the years after Islam entered the country, civil war broke out and relative stability in social life. During this relative stability, the opportunity for the development of cultural

\footnotetext{
${ }^{1}$ Zebiniso ODINAEVA, base doctor, philosophy and logic department, National University of Uzbekistan named after Mirzo Ulugbek, Uzbekistan.
} 
development, science and literature has been opened. One of the great thinkers of that period, Muhammad al-Khwarizmi, was prominent in Baytul Hikma, the Caliph al-Ma'mun. In the ideas that he put forward, the universal values of values were interpreted.1

The value of Khorazmiy's scientist was that his past had given the idea to the future. The Mutafakir writes: "In the past, the sciences of the science of science ...... were to refer to those who came after them by writing works in the field. One of them is beyond the reach of others who inherit it, leaving it inherited to those who come after it, and another interprets the works of those before them, thereby facilitating difficulties ...it does not behave indecently, and it does not boast of what it does. "2. These words are a common feature of the whole Oriental scholar, the criterion of maturity, the present-day intellectual property of the intellectual property.

Abu Nasr Farabi (873-959), who played an important role in the history of the Oriental culture, also valued values. The ideas of Farabi about the value can be clearly seen in the doctrine of "Madina al-fuzila". In the doctrine of the Forob in the doctrine of the human being, as a scientist, high ideals, just social relations, have explained the general system of moral-ethical values that arise in the wholesale period. In the Forobic society, religious values also have certain significance, but it emphasizes that the representatives of theology and jurisprudence govern the spheres that satisfy the spiritual and moral wellbeing of people, and that the main branches of social relations are regulated by philosophers.

At the time when the intellectual views of the Mutafakkir were the most important in the ideological sphere, it was not only the idea of God, but also one of the first Eastern philosophers who regarded the human, society, and scientific values as one of the main themes of philosophical sciences.

We talked about the legacy left over by some of our scientists, and we have described their significant features, and we can not even write a whole book about our great and longrange comic ages and our savvy scientists. It would be better to perceive the acheological power of these unique ages, when such works are read in the philosophical thinking and subsequently programmed in their own lives.

Today, the ongoing reforms in Uzbekistan, the analysis of innocent ideas, show that the rich spirituality of the Uzbek people is in search of its historical roots and the influence of our nation on the spirituality of the people of the world.

Because: Against the rogue religious trends all over the world, mankind can resist and destroy it only through its rich spiritual perfection. In this sense, the most valuable aspect of medieval Oriental philosophy is that the works created by our encyclopedia scientists at that time have literally only enriched the eternal spirituality of the Uzbek people, and is an ideological force that preserves the eternal spiritual-cultural, physical and spiritual perfection of all humanity.

References

S.Otamuratov.Globalization and Nation-T .: New Generation Generation, 2008.

[1] Karimov's call to action // Free and prosperous homeland, our free will is our ultimate goal. -T.: Uzbekistan, 2000.- T.8.-b.

[2] Karimov I. Spirituality, Marxism and Life-T .: Fan.2007.16 p.

[3] Q.Nazarov. Philosophy of Values-T: The Society of Philosophers of Uzbekistan, 2004, p.

[4] The history of social philosophy in Uzbekistan - T: Uzbekistan, 1995, p.

[5] Avesto. Yasht's book. The translation of Askar Mahkam. - Tashkent: East, 2001. - 112 p.

[6] Fayzullaev A.F. Nauchnoe tvorechestvo Mohammed al-Xorazme.-T .: Fan. 1983 y.

\footnotetext{
${ }^{1}$ Fayzullaev A.F. Nauchnoe tvorechestvo Mohammed al-Xorazme.-T .: Fan. 1983y.
} 
For notes 
For notes 
Scope Academic House

UK, S YORKSHIRE, SHEFFIELD

B\&M Publishing

USA, San Francisco, California

$7^{\text {th }}$ International Conference «Science and practice: a new level of integration in the modern world». Conference Proceedings. Scope Academic House, October 28, 2018, Sheffield, UK. Part 1.82 pp.

PQN 200

ISBN 978-1-941655-79-5

DOI: http://doi.org/10.15350/UK_6/7/1 